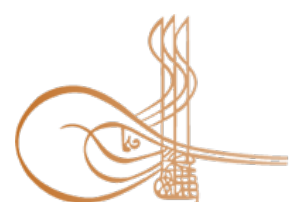

www.turkishstudies.net/history
Turkish Studies - Historical Analysis

eISSN: 2667-5552

Research Article / Araştırma Makalesi

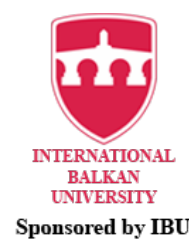

Sponsored by IBU

\title{
Cumhuriyet Döneminde Doğu Vilayetlerinde Yaşanan Doğal Afetler ve Yapılan Yardımlar (1923-1950)
}

\author{
Natural Disasters That Occured and the Aids That Were Made in Eastern Provinces in the \\ Republican Period (1923-1950)
}

\author{
Resul Köse*
}

\begin{abstract}
Natural disasters that human beings cannot prevent they occur and cause loss of life and property according to their impact; can be listed as earthquake, flood, drought/ famine, avalanche, rock fall and epidemic diseases. From time to time, Anatolia got its share from these disasters throughout the history. In this study, the subject of casualties and destruction caused by earthquakes, drought / famine, flood and flood in the Eastern and Southeastern Anatolia regions from 1923 to 1950, and the official and civil aids made to the victims who were suffered of these disasters. The purpose of limiting the study in this way is; To reveal the attitude of the Republican People's Party Government in power against these natural disasters and their help to the disaster victims. At the end of the study, it was observed that during this period, many disasters occurred in Eastern and Southeastern Anatolian provinces that caused loss of life and property. Earthquakes were the first among these disasters. But CHP Governments tried to lick the disaster victims' wounds as soon as possible, by mobilizing all the opportunities of the state and the people in all disasters. As the best example of state-nation solidarity in this regard, especially the Erzurum earthquakes in 1924 and Erzincan earthquakes in 1939 can be given as examples. After these earthquakes, the visits of the president of the republic Gazi Mustafa Kemal and the president of the republic Ismet Inönü to the disaster areas gladdened the victims' hearts and provided quick healing of the wounds. Archive documents and other sources were used in the study.
\end{abstract}

Structured Abstract: In this study, which examined the natural disasters in the Eastern Provinces during the Republican Period between 1923 and 1950, it was observed that there were many disasters in the region during the period.

The first earthquake occurred in Erzurum during this period. The first of the earthquakes in Erzurum occurred on 13 May 1924. The most violent one happened on September 13, 1924. The earthquake, which is also felt from the surrounding provinces, had the most devastating effect in Erzurum and Kars. The government tried to deliver cash and in-kind benefits to earthquake victims immediately. The president of the Turkish Republic, Mustafa Kemal, visited these two provinces hit by the earthquake. This disaster was the first serious experience of the Republican administration in providing aid by providing state-public integration.

After the earthquake in Erzurum, an earthquake occurred on the night of January 9, 1925, in Ardahan in the region. 140 people died in the earthquake. The Government and the Hilal-i Ahmer Society brought relief to the earthquake victims immediately and healed their wounds.

\footnotetext{
* Öğr. Gör. Dr., Sağlık Bilimleri Üniversitesi, Atatürk İlkeleri ve İnkılâp Tarihi Bölümü

Lect. PhD, University of Health Sciences Turkey, Atatürk's Principles and History of Turkish Revolution ORCID 0000-0002-4658-6778

resul kose80@hotmail.com/resul.kose@sbu.edu.tr

Cite as/ Atıf: Köse, R. (2020). Cumhuriyet Döneminde Doğu vilayetlerinde yaşanan doğal afetler ve yapılan yardımlar (1923-1950). Turkish Studies - History, 15(2), 565-595. https://dx.doi.org/10.29228/TurkishStudies.43160

Received/Geliş: 24 April/Nisan 2020

Accepted/Kabul: 20 June/Haziran 2020

Copyright $($ INTAC LTD, Turkey
} 
An earthquake occurred on 22 October 1926 this time, in Kızılçakçak, Kars. Fifteen villages in Karswere affectedby the earthquake, and 373 households were either completely or partially destroyed.

An earthquake occurred in Van Başkale in May 1930. 51 people died and 48 were wounded. The government and Hilal-i Ahmer provided the necessary assistance on time.

On 5/6 January 1931, there was an earthquake in Iringil sub-district of Elaziz province. 12 houses were collapsed in the earthquake and 117 houses were cracked. However, there was no loss of life.

Kiğ 1 earthquake occurred on May 2, 1935. 40 buildings were completely destroyed and 155 buildings were partially destroyed in the earthquake.

On May 1, 1935, a violent earthquake centered in Kars Digor was experienced in the region. In the earthquake, 638 houses were destroyed in 31 villages in Digor sub-district. 73 people died and 125 people were injured. 12 people died in the district of Kağızman. In the district of Arpaçay, 4 people were injured and 50 houses were destroyed. The earthquake victims received assistance from the Kars Governorate, Kars Hilal-i Ahmer Branch, and the government.

Five earthquakes occurred on 16, 18, 19, and 23 March 1936 in the sub-district of Digor in Kars and the sub-district of Kötek in Kağızman. Around 200 buildings were destroyed in this shock. There was no loss of life.

An earthquake occurred in the district of Tercan, Erzincan on November 21, 1939. The earthquake was felt in the districts of Central, Kemah, Tercan in Erzincan province. In the earthquake, 6 women and 21 children died under the rubble and 56 people were injured. While the Erzincan governorship and Tercan district governorship helped earthquake survivors, the Red Crescent also provided the necessary assistance.

One of the biggest earthquakes seen in Turkey and world history was undoubtedly 27 December 1939 at around two o'clock, a 7.9 magnitude Erzincan-based earthquake. In this earthquake, all buildings, including the official buildings in Erzincan, were completely destroyed. That great earthquake was felt in many provinces such as Erzincan and Sivas, Amasya, Tokat, Samsun, Ordu, Giresun, Gümüşhane, Yozgat, Malatya and Tunceli and had devastating consequences. While the government took the first measures to help earthquake survivors, the National Aid Committee was set up in the parliament. The ministers of the Interior and Health were only able to reach Erzincan on 31 December 1939 due to the roads closed. On the same day, the president of the Turkish republic Ismet Inönü came to Erzincan to share the suffering of the people. This earthquake was so severe that a total of obi:32,736 people lost their lives in all of the provinces mentioned above, while 9,402 people were injured. In Erzincan, which was hit hardest by the earthquake, 15,740 people died and 4,117 were injured. While the aid to the earthquake survivors was made in the first days, the government rolled up its sleeves for permanent aid. In this context, the reconstruction of Erzincan city, which was hit most by the earthquake, was considered on a preferential basis. On 22 June 1940, the government issued a decree on the use of the land $5.5 \mathrm{~km}$ north of old Erzincan for the city of new Erzincan. Domestic and foreign aid to earthquake survivors were gathered under the coordination of the National Aid Committee for about a year. The committee was delivering these aids to the Red Crescent. By November 27, 1940, the total amount of all cash assistance from inside and outside had been 5,325,870.44 pounds. 1,420,727. 47 Turkish liras had come from foreign countries. The remaining 3,905,142. 97 Turkish liras had been collected from the inland. Apart from these cash aids, food, goods, and sanitary supplies were provided to meet the needs of earthquake victims from inside and outside.

On 11 September 1941, an earthquake centered on Kocapınar sub-district, Erciş district, Van province. From the first moment, the Red Crescent and the civilian and military authorities for the emergency of the earthquake victims immediately took action. In the earthquake, 90 dead citizens were taken out from under the rubble.

1945 was a nightmare for Van. The earthquakes of Van that started on June 28 continued for seven consecutive months. The government and the Red Crescent met all the needs of the earthquake victims.

An earthquake occurred in Varto, Muş on May 31, 1946. The center and villages of Varto were affected by the earthquake.

390 people died and 100 people were injured in the earthquake. 
On 17 August 1949, an earthquake in Bingöl occurred. Erzurum, Çat, Bingöl, Karlıva, Kiğı̆, Erzincan, Tercan and Nazımiye were affected by this earthquake. There were 163 dead and nearly 100 wounded in Karlova, while there were 83 dead and more than 100 wounded in Kiği. More than 400 houses in Karlıova and 500 in Kiğı were completely collapsed, and many houses became uninhabitable.

In the eastern and southeastern Anatolia regions, as in every geography, there were natural disasters caused by drought/famine, floods caused by excessive rainfall, and flood runoff. These disasters sometimes caused loss of life and property.

Against all these disasters that occurred between 1923-1950, the Republic of Turkey, in less than a year after all the issues on its front to eliminate the damages, was mobilized to heal the wounds of the victims. In the earthquake, in 1924, Erzurum, Gazi Mustafa Kemal personally went to the earthquake zone and gave the message that the state was with the victims both as materially and spiritually. During that visit, Gazi also started an aid campaign throughout the country to heal the wounds of the victims of the disaster. Thus, thanks to the state-nation mobilization, the wounds of the earthquake were quickly healed. Another good example was Erzincan earthquake in 1939, in which all of the Turkish nation took part in the face of a disaster, regardless of whether it was far or near. In this earthquake, the President of the time, İsmet İnönü went to the earthquake zone and shared the pain of the earthquake victims. The fact that the nation was united and rushed to the aid of the victims with its state was a situation that we encountered in all disasters during the period. This situation is the most beautiful example of people living in the same geography together in joy and together in difficult times as well as fulfilling the necessity of being a nation by relieving the pain.

Keywords: Natural Disasters, Earthquake, Drought/ Famine, Flood, Eastern And Southeastern Anatolian Provinces.

Öz: İnsanoğlunun yaşanmasına engel olamadığı ve etkisine göre can ve mal kayıplarına sebebiyet veren doğal afetler; deprem, sel, kuraklık/kıtlık, çı̆̆, kaya düşmesi ve salgın hastalıklar șeklinde sıralanabilir. Bu afetlerden tarih boyunca Anadolu da zaman zaman nasibini aldı. Bu çalışmada Cumhuriyet Dönemi'nde 1923 yılından 1950 yılına kadar Doğu ve Güneydoğu Anadolu bölgelerinde yaşanan deprem, kuraklık/kıtlık, sel ve taşkın gibi doğal afetlerin sebep olduğu zayiat ve tahribat ile bu afetlerde mağdur duruma düşen afetzedelere yapılan resmi ve sivil yardımlar konusu incelenmiştir. Çalışmanın bu şekilde sınırlandırılmasındaki maksat ise bu yıllarda iktidarda olan Cumhuriyet Halk Partisi Hükûmetlerinin yaşanan doğal afetler karşısındaki tutumunun ne olduğunu ve afetzedelere yaptığı yardımları ortaya çıkarmaktır. Çalışma sonunda görülmüştür ki bu dönemde Doğu ve Güneydoğu Anadolu vilayetlerinde can ve mal kaybına yol açan birçok felaket yaşanmıştır. $\mathrm{Bu}$ felaketler içerisinde depremler ilk sırada yer almıştır. CHP Hükûmetleri ise yaşanan tüm felaketlerde hem devletin hem de halkın tüm imkânlarını seferber ederek felaketzedelerin yaralarını bir an önce sarmaya çalışmıştır. Bu konuda devlet-millet dayanışmasının en güzel örneği olarak özellikle 1924 yılında yaşanan Erzurum ve 1939 yılında yaşanan Erzincan depremleri örnek olarak verilebilir. Bu depremlerin ardından Reisicumhur Gazi Mustafa Kemal ve Reisicumhur İsmet İnönü'nün felaket bölgelerini ziyaretleri felaketzedelerin yüreklerine su serpmiş ve yaraların bir an önce sarılmasını sağlamıştır. Çalışmada arşiv belgeleri ve diğer kaynaklardan istifade edilmiştir.

Anahtar Kelimeler: Doğal Afetler, Deprem, Kuraklık/Kıtlık, Sel, Doğu Ve Güneydoğu Anadolu Vilayetleri.

\section{Giriş}

Doğal afetler; deprem, sel, kuraklık/kıtlık, çığ, kaya düşmesi ve salgın hastalıklar şeklinde siralanabilir. Bu afetlerden tarih boyunca Anadolu da zaman zaman nasibini aldı. (Pampal, 2000:) Bu çalışmada Cumhuriyet Dönemi'nde 1923 y1lından 1950 y1lına kadar Doğu ve Güneydoğu Anadolu bölgelerinde (Darkot, 1955) yaşanan deprem, kuraklık/kitlık, sel ve taşkın gibi doğal afetlerin sebep olduğu zayiat ve tahribat ile bu afetlerde mağdur duruma düşen afetzedelere yapılan resmi ve sivil yardımlar konusu incelenmiştir.

$\mathrm{Bu}$ afetleri işlerken bölgede bu tarih aralığında yaşanan büyüklü küçüklü afetlerin hepsini incelemedik. Yalnızca can kaybının olduğu ve ciddi anlamda mal kaybının yaşandığı deprem, kuraklık/kıtlık, sel ve taşkın afetlerini inceledik. Bölgede bu tarih aralığında yaşanan salgın 
hastalıklar konusu daha önce işlendiği için (Köse, 2019: 455-473) bu çalışmayla birlikte ülkenin Doğu vilayetlerinde yaşanmış olan doğal afetler konusu böylelikle bir bütün olarak ortaya çıkarılmış olacaktır. Çalışmanın tarih aralığını 1923-1950 yılları olarak sınırlandırmamızın sebebi ise malum olduğu üzere bu dönem ülkeyi Cumhuriyet Halk Partisi (CHP) yönetmektedir. Yani aslında bu çalışma ile biz CHP iktidarında bölgede yaşanan doğal afetlere karşı devletin tutumu ve sosyal devlet anlayışı gereğince yapılan yardımlar bahsini de ortaya koymuş olacağız.

\section{A. Depremler ve Yapılan Yardımlar}

İnsanoğlunun yaşadığı doğal afetler içerisinde depremler etkileri açısından ilk sırada yer almaktadır. Öyle ki doğal afetlerin yüzde sıralaması içerisinde depremler \%61'lik bir orana sahiptir. Anadolu, Dünya üzerindeki en etkin deprem kuşaklarından biri olan Akdeniz-Alp-Himalaya kuşağında yer almaktadır. Bu deprem kuşağı üzerinde Dünyadaki toplam depremlerin beşte biri meydana gelmektedir. "Bu kuşak, birbirine karşıt olarak uzanan kirlkların oluşturduğu bir ă̆ görünümü ile Türkiye'yi, Kuzey, Güney ve Batı'dan üç asli kırlk sistemiyle kat etmekte, bu asli sistemlere, yerel kirlk zonlar da eklenmektedir. Deprem haritası ve bu haritaya esas sismisite verilerine göre, Türkiye topraklarının \% 93 'ü deprem bölgeleri içinde yer almaktadır." (Türkiye'de Deprem Gerçeği, 2012: 3, 7)

\section{Erzurum Depremi (1924)}

Cumhuriyet Dönemi'nde Doğu vilâyetlerinde ilk olarak Erzurum'da deprem olmuştu. Depremin merkezi Erzurum olsa da deprem civar vilayetlerden de hissedilmişti. (BCA, Fon No: 30 1811 Yer no: 11431 )

Erzurum'daki depremler silsilesinin ilki 13 Mayıs 1924'te vuku buldu. Horasan çevresinde etkili olan bu deprem merkezde pek tesirli olmamış, herhangi bir can kaybına yol açmamıştı. (Atnur, 2006: 27) Ancak yıkılan evler, kaybedilen mallar olmuştu. Bunların telafisi için İcra Vekilleri tarafindan 19 Mayıs 1924, (BCA, Fon No: 301811 Yer No: 925 9) 8 Haziran 1924 (BCA, Fon No: 301811 Yer No: 1029 7) ve 3 Ağustos 1924 (BCA, Fon No: 301811 Yer No: 37 109) tarihli Kararnameler ile felaketzedelere 20'şer bin lira yardım yapılması kararlaştııılmıştır.

Yaşanan bu depremin yaraları sarılmaya çalış1lırken 6 Eylül 1924'te bir deprem daha meydana geldi. Üçüncüsü ve en şiddetlisi ise 13 Eylül'de yaşandı. Deprem çevre illerden de hissedilmiş zayiata sebebiyet vermişti. Bu yerlerden Kars ile Erzurum merkez ve kazalarındaki depremzedelerin yaralarını sarmak için 10 Eylül 1924'te 20 bin lira (BCA, Fon No: 301811 Yer No: 1143 1) ve 17 Eylül 1924'te 40 bin lira (BCA, Fon No: 301811 Yer No: 1143 15) yardım yapılmıştı.

Yapılan maddi yardım haricinde depremzedelere manevi destek için devletin en tepesindeki isim, Reis-i Cumhur Gazi Mustafa Kemal, Erzurum felaketini yerinde görmek için o sırada bulunduğu Karadeniz ziyaretini yarıda keserek Erzurum, Sarıkamış ve Kars'ı ziyaret etmişti. 30 Eylül 1924 tarihinde Erzurum'a gelen Gazi, burada halka yaptığı konuşmada depremden dolayı bütün bir milletin üzüldügüunü, herkesin bu felâketin yaralarını sarmak için maddî manevi bölge halkına şefkat elini uzatacağını söyleyerek (Atatürk'ün Söylev ve Demeçleri, 1997: 211) depremzedelere moral vermeye çalışmıştı.

Dönemin aydınlarından Ahmet Hamdi Bey [Tanpınar] Erzurum depremini yaşayanlardandı. Tanpınar, bu deprem ve Reis-i Cumhur Mustafa Kemal'in Erzurum ziyaretine ilişkin hatıralarında bahsetmektedir. O'nun verdiği bilgilere göre deprem, Merkez harici özellikle kazalarda daha çok tahribata sebep olmuştu. Yaklaşık bir ay devam eden sarsıntılardan dolayı halk evlerine uzunca bir süre girmemişti. İşte bu günlerde Erzurum'a gelen Gazi, halkın ısrarlı uyarılarına rağmen çadırda kalmayıp çatlaklar oluşmuş hükûmet konağında kalmıştı. Böylelikle halk da artık çadırlardan çıkmış ve evlerine girmişti. (Tanpınar, 1960: 54-55) 
1 Ekim'de Gazi, Vali Zühtü Bey başkanlığındaki "Felaketzedegan Komisyonu" ile toplantı yaptı. Toplantıda bir çalışma programının hazırlanması kararlaştırıldı. Ayrıca Gazi, eşi ile beraber 10.000 'er lira yardımda bulunarak ülke çapında yayılacak olan bir yardım kampanyasını başlattı. Bu şekilde yurdun muhtelif yerlerinden toplanıp gelen para (Hâkimiyeti Milliye, 16-30 Eylül 1924; Çapa, 651-655; Kalemli, 2010: 1-19) 1924 yılı sonuna kadar 300 bin lirayı bulmuştu. (Küçükuğurlu, 2012: 573)

Bu ziyaretin hemen ardından Hükûmet, 2 Ekim 1924 tarihli bir Kararname ile felaketzedeler için 50 bin lira daha yardım yapılmasını kararlaştırmıştı. (BCA, Fon No: 301811 Yer No: 11462 lef 1) Hükûmet 4 Ekim 1924 tarihinde ise depremin yaralarını biran önce sarmak için bir heyet teşkiline karar verdi. Askeri üyelerin de yer aldığı bu heyete, yapılacak yardımlar konusunda askeri ambarlardan, Şark şimendiferlerinden ve Sarıkamış ormanlarından kereste ihtiyacı için yardım alabilmesine dair yetki verilmişti. (BCA, Fon No: 301811 Yer No: 11468 lef 2) 8 Ekim 1924 tarihinde askerlerden fiilen yardım için ayrılan ve tahsis olunan kuvvetler deprem bölgelerine varmışlar ve çalışmalara başlamışlardı. Sarıkamış ormanlarında kereste ve ağaç kesilmesine başlanılmıştı. (BCA, Fon No: 30100 Yer No: 40237 12; BCA, Fon No: 3010007 Yer No: 117 $8183)$

Gazi Mustafa Kemal, bu günlerde Erzurum'un Merkez ve ilçelerinin yanı sıra Kars ve Sarıkamış'ı da ziyaret etmişti. Aynı zamanda Muş ve Bitlis'ten gelen ziyaretçilerle de Erzurum'da 9 Ekim'de görüşmüştü. Gazi, 10 Ekim'de ziyaretini tamamlayarak Erzurum'dan ayrıldı. (Küçükuğurlu, 2010: 572-577)

Hükûmet, depremde evsiz kalanlar için yaklaşan kış mevsiminden dolayı acilen barınma sorununu çözmek istiyordu. Bu iş için Meclis'ten bir kanun çıkartılması gerekmişti. 24 Ekim 1924 tarih ve 516 sira sayılı Kanun ile Erzurum ve civarı vilayetlerde depremden yıkılan meskenlerin inşası ve felaketzedelerin barındırılması için yapılacak satın almanın pazarlık suretiyle icrası kararlaştırıldı. (TBMM Zabıt Ceridesi, Devre 2, İçtima Senesi 2, Cilt 9, s.49-50; Resmî Cerîde, 24 Kasım 1924, Sayı: 79)

Doğu vilâyetlerinde yaşanan bu deprem felâketi, Cumhuriyet yönetiminin devlet-halk bütünleşmesinin sağlanarak yardımların yapılması hususunda ilk ciddî deneyim olmuştur. Devletin en üst makamı olan Reis-i Cumhur Gazi Mustafa Kemal'in bizzat deprem mahalline gelmesi, sorunları yerinde görmesi, ihtiyaçları tespit ettikten sonra yapılacak olan yardımların doğru ve hızlı bir şekilde ulaştırılmasını temin gerçekten önemli idi. Yapılacak olan yardımlara bizzat kendisinin de bağışta bulunup yurt sathında bir kampanya başlatması da toplumsal dayanışma adına çok anlamlı bir hareket olmuştu. Bu da Gazi'nin zor zamanlarda milleti bir araya getirebilme özelliğinin ya da diğer bir deyişle liderlik yönünün güzel bir örneği olarak karşımıza çıkmıştır.

\section{Ardahan Depremi (9 Ocak 1925)}

Erzurum depreminden sonra bölgede, Ardahan'da 9 Ocak 1925 gecesi deprem meydana gelmişti. (BCA, Fon No: 301811 Yer No: 1268 9)

6 şiddetinde hissedilen bu depremde Ardahan'a bağlı dört köy haritadan silinirken, bir köy de kısmen yıkılmıştı. Depremde 140 kişi hayatını kaybetti. Bu rakam o yıllardaki Ardahan nüfusunun neredeyse üçte biri idi. Depremzedelerin yardımına Hilâl-i Ahmer Cemiyeti koşmuştu. Cemiyet ilk yardım olarak hemen bu günlerde Ardahan merkeze 1.000 battaniye, 1.000 fanila, 1.000 don, 1.000 gömlek, 1.000 çift çorap ile 1.500 lira para gönderdi. Yine Erzurum Hilâl-i Ahmer Şubesinin elinde bulunan tıbbi malzeme, cerrahî alet ve sıhî gereçlerden yeterli miktarda Ardahan'a gönderildi. Soğuk kış şartları yardımların Ardahan'a ulaştırılmasını güçleştirmişti. Beraberlerinde yardım malzemeleri de taşıyan yardım heyeti -40 derecede bin bir güçlükle Ardahan'a ulaşabilmişsi. (Tekir, 2012: 423-436) 
Hilâl-i Ahmerin bu yardımları haricinde Hükûmet depremzedelere başka yardımlar da yapmıştı. Deprem sebebiyle Ardahan merkez ve bağlı kazalarda can ve mal kaybı oldukça fazla olduğu için Hükûmet, 11 Ocak 1925 'te 10 bin lira para gönderilmesini kararlaştırmıştı. (BCA, Fon No: 301811 Yer No: 1268 9) Gönderilen bu paranın yetmemesi üzerine 15 Ocak 1925'te 10 bin liranın daha gönderilmesi kararlaştırılmıştı. (BCA, Fon No: 301811 Yer No: 1269 2)

\section{Kars Kızılçakçak Depremi (22-23 Ekim 1926)}

22 Ekim 1926'da bu sefer Kars Kızılçakçak'ta bir deprem meydana geldi. Deprem ile ilgili ilk bilgileri Dâhiliye Vekili 24 Ekim'de Başvekâlete bildirdi. Buna göre Kızılçakçak'ta meydana gelen depremde hasara uğramamış resmi ve hususi bina kalmamıştı. Nüfusça zayiat yok ise de asker ve hayvanat açıkta kaldığından geçici olarak iskânları için boş olarak mevcut vagonlardan en azından otuz adedinin Kızılçakçak'a gönderilmesi lüzumu Şark Hudut Komiserliğine bildirilmiş ve icap edenlere emir verilmesi için de Nafia Vekâletine yazılmıştı. (BCA, Fon No: 3010007 Yer No: 119 8377 lef 1)

Deprem ile ilgili zayiat ve hasar miktarına ilişkin daha sonra Dâhiliye Vekili Kars Vilayetinden gelen rapora atfen 28 Ekim 1926 tarihinde Başvekâlete ayrıntılı bir rapor sundu. Buna göre Kızılçakçak'ta vuku bulan depremde can kaybı yaşanmamıştı. Deprem 22 Ekim gecesi başlayıp 23 Ekim sabahına kadar aralıklarla beş defa vuku bulmuştu. Güney taraftan gelen birinci ve ikinci depremler hafif olduğundan hasar olmamış ve halkı ikaz ile evlerinden dışarıya çıkmalarına ve canlarını kurtarabilmelerine fırsat vermişti. Üçüncü deprem binaları yıkmıştı. Vilayet dâhilinde hemen bütün kaza ve köylerde hissedilen bu depremler bilhassa Gümrü civarındaki Alagöz Dağı'yla Arpaçay kazasının Kızılçakçak ve Başgedikler nahiyelerine bağlı toplam on beş köyde (Pirveli, Uzun Kilise, Küçük Ergine, Möküz, Akbulak, Dalavir, Küçük Kımılı, Büyük Kımılı, Büyük Ergine, Küçük Aküzüm, Büyük Aküzüm, Balananl1, Kesimiki, Morgin, Kızılçakçak) farklı şiddetlerde hissedilmiş ve hasara yol açmıştı. Bu köylerdeki toplam 619 haneden 373 hane ya tamamen ya da kısmen yıkılmıştı. Özellikle Pirveli köyünde bulunan 47 binanın tamamı yıkılmıştı. (BCA, Fon No: 30100 07 Yer No: 1198377 lef 2) Kars-Gümrü şosesinde harap olan kısım üzerinde geliş gidişin teminine lüzumlu tamiratın icrası için Vilayetten hemen fen memurları ile amele sevk edilmişti. Vilayet dâhilindeki metruk köylerde oturmaya müsait haneler tespit edilmişti. Felaketzede ahaliden muhtaç olanlara yardım etmek hususu Hilâl-i Ahmer Cemiyeti Riyasetinden rica edilmişti. (BCA, Fon No: 3010007 Yer No: 1198377 lef 1)

\section{Van Başkale Depremi (Mayıs 1930)}

1930 yılı Mayıs ayında Van Başkale'de deprem yaşandı. Van vilayetinin 17 Mayıs 1930 tarihinde Dâhiliye Vekâletine bildirdiği deprem raporuna göre bu felakette, 51 kişi hayatını kaybederken 48 kişi de yaralı olarak kurtuldu. Depremde 37 at, 25 kısrak, 11 tay, 29 manda, 139 öküz, 206 inek, 88 dana, 1.435 koyun, 1.224 kuzu, 584 keçi, 328 oğlak, 34 toklu, 5 tosun, 3 merkep enkaz altında kalarak telef oldu. 9 köy de tamamen yıkıldı. Dâhiliye Vekili Şükrü Kaya gereken yardım konusunda bu durumu 22 Mayıs 1930'da Başvekâlete bildirdi. (BCA, Fon No: 301000 Yer No: 119845 14) Yine Başkale depremzedelerine yardım için Hilâl-i Ahmer de devreye girmişti. Depremden evleri yıkılıp açıkta kalan Başkaleliler için Hilâl-i Ahmer Cemiyeti yardım yapmıştı. Başkale'deki Hilâl-i Ahmer memurları depremzedelere iki aylık iaşe dağıttı. Bu hareket depremzedeleri hayli memnun etti. (Hâkimiyeti Milliye, 7 Haziran 1930)

\section{Elâziz İringil Depremi (5/6 Ocak 1931)}

5/6 Ocak 1931'de Elâziz vilayeti İringil nahiyesinde deprem olmuştu. Depremde $12 \mathrm{ev}$ yıkılmış 117 evde de çatlaklar oluşmuştu. Ancak can kaybı yoktu. Hayvan olarak ise 10 keçi telef olmuştu. Yine Hoh nahiyesinde iki ahır yıkılmış 8 hayvan telef olmuştu. Hilâl-i Ahmer tarafından depremzedelere çadır dağıtılmıştı. (BCA, Fon No: 3010007119838 1) 


\section{Kiğı Depremi (2 Mayıs 1935)}

Bölgede yaşanan depremlerden biri de 2 Mayıs 1935 tarihinde vuku bulan Kiğ depremi idi. Bu deprem 2 Mayıs saat 12.45 'te Kiğı kazası ve köylerinde hissedilmişti. Depremde Kiğ köylerinde; 97 ev kaza merkezinde, 46 ev Kadıköy'de, 27 ev ve iki değirmen Abvan köyünde, 12 ev Hogas köyünde, 10 ev Ölmezli köyünde, bir ev de Hösnek nahiyesinin Azakpert köyünde olmak üzere 195 binadan 40 bina tamamen ve 155 bina da kısmen yıkılmıştı. Depremde kazadaki hükûmet binas1 ve mektep de zarar görmüştü. Erzincan vilayeti depremzedeler için acil olarak Erzincan Hilâli Ahmer Cemiyetinin topladığı 65 lirayı göndermiş diğer ihtiyaçlar için de Dâhiliye Vekâletinden 5 Mayıs 1935'te para ve çadır isteğinde bulunmuştu. (BCA, Fon No: 301000 Yer No: 11983910 lef 2)

\section{Kars Digor Depremi (1 Mayıs 1935)}

1 Mayıs 1935 tarihinde bölgede Kars Digor merkezli şiddetli bir deprem yaşanmıştı. Dâhiliye Vekili Şükrü Kaya, Digor'da yaşanan depremi Kars Valisi Cevdet Ertuğrul'dan gelen telgrafi 4 Mayıs 1935 'te Mecliste okuyarak bu üzücü olayı milletvekilleri ile paylaşmıştı.

Gelen telgrafa göre Vali, deprem yaşanır yaşanmaz hemen vaziyeti anlamak için Digor nahiyesine gitmişti. İlk edinilen bilgilere göre deprem yer altında oluşan çöküntüden meydana gelmişti. Depremin merkezi Digor nahiye merkezi civarıydı. Yaklaşık 50 kilometre yarıçapında sarsıntılar tesirini göstermişti. Bu dairenin merkezinden itibaren 15 kilometre muhitindeki köyler tamamıla harap olmuștu. Zayiat da bu muhit içindeydi. Bunun haricindeki kısımda evler kısmen yıkılmış ve büyük bir kısmı çatlamak suretiyle zarara uğramıştı. Bu hâdisede Digor nahiyesi dâhilindeki 25 köyden 709 ev tamamen yıkılmıştı. Bu nahiye ve köylerinde 68 kişi hayatını kaybederken 70 kişi yaralı olarak kurtulmuştu. Sekiz kişinin de kayıp olduğu tespit edilmişti. Hayvan zayiatı ise oldukça fazlaydı.

Depremin vurduğu Kağızman kazası mıntıkasında ve Digor nahiyesine sınır olan dört köyde 30'a yakın ev yıkılmış ve iki kişi yaralanmıştı. Hayvan zayiatı buralarda yoktu. Arpaçay kazasının yine Digor nahiyesine sınır olan köylerinde bazı evler yıkılmış ve bazıları hasara uğramıştı. Digor nahiyesinin sınırına tesadüf eden merkez kazası köylerinde de 50 kadar hane yıkılmıştı. İnsan zayiatı yoktu ancak hayvan telefatı vardı. Bu sarsıntı tesiriyle nahiyeye giden şose üzerinde köprü ve menfezler de kısmen yıkılmıştı.

Vali bu bilgileri paylaştıktan sonra felaketzedelere yapılan ve yapılması gereken yardımlardan bahsetmişti. Verilen bilgiye göre açıkta kalan felaketzedelere Kars halkından 520 lira ve Hilâl-i Ahmerin Kars Şubesinden 430 lira ile Kars'taki un fabrikasının bağışladığı 30 çuval un dağıtılmıştı. Bazı köylere de 37 çadır askeriyeden alınarak dağıtılmıştı. Yıkılan köylerin halkı açıktaydı. Bu sebeple bir an evvel evlerinin inşasına yardım etmek gerekiyordu.

Bunlara iaşe yardımı olarak 2.000 lira lâzım olduğu gibi ev inşaatına hane başına 40-50 lira arasında yardım yapılması gerekmekteydi. Bunun için de 40.000 lira lâzımdı. Vali isteğin 2.000 lirasının Hilâl-i Ahmerden karşılanması ve inşaat için de lâzım olan 40.000 liranın ne suretle tedarik edilmesi icap ediyorsa ona göre bir an önce karşılanmasını istemişti.

Dâhiliye Vekili Şükrü Kaya bu telgrafi okuduktan sonra gerek mahallî tedbir, gerek Hükûmetin aldığı tedbirler gerekse Hilâl-i Ahmerin kısa zamanda yapacağı yardımlar sayesinde felaketzedelerin yaralarının bir an önce sarılacağını ve halkın tez zamanda bir çatı altına alınacağını söylemişti. (TBMM Zabıt Ceridesi, C. 3, Devre 5, İçtima F., 1935:39-40)

Deprem ile ilgili Akşam gazetesinin hususi muhabirinin verdiği bilgiler de vardı. Bu bilgiler Şükrü Kaya'nın Meclis'te yaptığı konuşmanın aynı günü, 4 Mayıs tarihli sayıda yayınlanmıştı. Buna göre enkaz altına kalanları kurtarmak için mıntıkaya amele postaları gönderilmişti. Köylerde zayiat çok fazlaydı. Pek çok bina yıkılmıştı. İnsan kaybı 500'ü bulmaktaydı. Yaralıların sayısı ise 1200'ün 
üzerindeydi. Depremzedelere yardım için İçişleri ve Sağlık ve Sosyal Yardım Bakanlığı, Kars vilayetine gereken tedbirlerin alınması talimatını vermişti. Hilâl-i Ahmer Cemiyeti de mıntıkada faaliyete geçmişti. Yine Digor'a Erzurum'dan bir operatör ile sıhhat memuru gönderilmişti. (Akşam, 4 Mayıs 1935)

Depreme dair ayrıntılı bilgiyi ve Sihhat ve İçtimai Muavenet Vekâletiyle sivil toplum kuruluşları ve halkın yaptığı yardımları daha sonra Vekâletin, Başvekâlete gönderdiği 19 Mayıs 1935 tarihli rapordan öğrenmekteyiz.

Rapora göre Digor nahiyesinde 31 köyde mevcut 959 evden 638'i yıkılmıştı. Depremden en çok Digor ile Susuz, Zibni, Başnık, Celali, Beşkilise köyleri etkilenmiş bu köylerden 73 kişi hayatını kaybetmiş, 125 kişi de yaralanmıştı. Yaralılardan 15 ağır yaralı memleket hastanesine kaldırılmıştı.

Kağızman kazasındaki köylerde binalar çatlamış, Serhunlu köyündeki bütün evler yıkılmış 12 kişi ölmüştü.

Arpaçay kazasında bazı evler hasar görmüş, Alaca köyünde 2 ve Ani köyünde 2 kişi yaralanmıştı. Merkez kaza köylerinde 50 ev yıkılmıştı. Mıntıka genelinde yıkılan ev sayısı vilayet raporuna göre 838 idi. Açıkta kalanların sayısı 2.954 kişiydi.

Depremzedeler için ilk yardım olarak; Vilayetçe Memleket Hastanesi operatörü ve Merkez Hükûmet tabibinden oluşan bir sağlik heyeti kurularak gerekli sıhhi malzeme ile deprem mıntıkasına gönderilmişti. Açıkta kalanlar için Kars halkı tarafından 520 lira ve Kars Hilâl-i Ahmer Şubesinden 430 lira, Kars un fabrikasından 30 çuval un, askeriyeden 37 çadır verilmişti. Hilâl-i Ahmer Genel Merkezinden iaşe için 2.000 ve yıkılan evlerin yapılması için 20.000 lira gönderilmişti. Bununla birlikte Erzurum Numune Hastanesinden bir tabip ve Erzurum vilayetinden bir seyyar tabip ve iki sıhhat memuru lüzumu kadar sıhhi malzeme ve Erzurum Hilâl-i Ahmer Şubesinde bulunan 30 çadırla bölgeye gitmişti. Erzurum'dan gönderilen iki tabipten biri ve bir sıhhat memuru Kağızman köylerine sevk edilmiş ve felakete uğrayan köylerdeki yaralılar tamamen tedavi edilmişti. Açıkta kalanlar yerleştirilmişti. Bunların un, ekmek ve saire ihtiyaçları da karşılanmıştı. (BCA, Fon No: 30100 0/119 83911 lef 1)

$\mathrm{Bu}$ yardımlara ilave olarak Çoruh vilayetinden 200 lira, Kars milletvekillerinden Baha Tali'den 100 lira, Hopa kazasından 300 lira, Sovyet Konsolosluğundan da 25 lira yardım yapılmıştı. (BCA, Fon No: 30100 0/119 83911 lef 2)

20 Haziran 1935 tarihinde ise evleri yıkılanlar için Hilâl-i Ahmer'e verilmek üzere Maliye bütçesinden 40 bin liranın tahsis edilmesi Hükûmet tarafından kararlaştırılmıştı. (BCA, Fon No: 30 1812 Yer No: 5652 18)

\section{Kars Depremleri (Mart 1936)}

$\mathrm{Bu}$ yıllar Kars vilayetinin adeta felaket yıllarıydı. Kars vilayeti 1935 yılında yaşanan depremin yaralarını sarmaya çalışırken 1936 yılında aralıklarla günlerce süren deprem felaketini yaşamıştı.

Bu depremler hakkında Kars Valisi Akif İyidoğan 24 Mart 1936 tarih ve 636, 637 sayılı yazılar ile vaziyeti Dâhiliye Vekâletine bildirmişti. Buna göre Kars'ın Digor nahiyesinde ve Kağızman'ın Kötek nahiye merkezinde 16, 18, 19 ve 23 Mart 1936 günlerinde beş defa deprem olmuştu. Bu sarsıntıda 200 kadar bina yıkılmış, iki inek ve üç koyun telef olmuştu.

23/24 Mart 1936 gecesi saat 21.40'ta vuku bulan bir sarsintıda da, Kötek nahiyesine bağl1 Ağver köyünde 22, Karakuş köyünde 20, Orta Tabiye'de 1, Kızılveran köyünde 24 bina yıkılmış 24 koyunla 9 sığır telef olmuştu. Ancak sevinilecek taraf bu depremlerde can kaybının yaşanmamasıydı. Dâhiliye Vekâleti bu bilgileri Başvekâlet makamına iletirken aynı zamanda depremzedelere bir an 
önce yardım ulaştırılması için Sıhhat Vekâleti ile Kızılay'a gerekli yazıların yazıldığını da belirtmişti. (BCA, Fon No: 301000 Yer No: 119840 5)

Vali Akif İyidoğan devam eden depremler ve bu depremlerin sebebiyet verdiği zayiat hakkında 26 Mart 1936'da 670 sayılı bir rapor daha yazmıştı. Buna göre 23 Mart 1936 gecesi saat 22.15 'te Digor nahiyesinde deprem olmuş ancak can kaybı yaşanmamıştı. Kağızman, Kötek, Karakuş, Ağveran köylerinde 24/25 Mart 1936 gecesi yer sarsıntısı devam etmişti. Yapılan tespitlere göre Konk'ta 44 ev, 21 oda, 22 samanlık, 43 ahır ve 17 kom tamamen yıkılmıştı. 32 ev, 39 ahır, 53 oda, 24 kom ve 39 samanlığın da duvarı çatlamıştı. Karakaş köyünde üç ev, 7 ahır, 5 oda ve 3 kom ile 6 samanlık yıkılmış, iki ahır, dört oda, bir kom, bir de samanlığın duvarları çatlamıştı. Ağveran köyünde altı ev, dokuz ahır, dört oda, dört kom ve dört samanlık yıkılmış, dört ev, beș ahır, 11 oda, iki kom, bir samanlığın duvarları çatlamıştı. Depremde can kaybı olmamıştı. Evsiz kalan halkın teskini için Pazar kaymakamı deprem mahalline gönderilmiş ve depremzedelerin iaşelerinin temini için de yardımlar yapılmıştı. Depremzedelerin barınmaları için de yeterli miktarda çadırın gönderilmesi telgrafla Dokuzuncu Kol Ordu ile Erzurum vilâyetine rica edilmiş̧i. Yine bununla birlikte Dâhiliye, Sıhhat ve Üçüncü Umumi Müfettişliğe, Kızılay ve Genelkurmay Başkanlıklarına da yazı yazılmıştı. (BCA, Fon No: 301000 Yer No: 1198405 lef 3)

Vali Akif İyidoğan ertesi gün, 27 Mart'ta son durum ile ilgili olarak Dâhiliye Vekâletine bir rapor daha yazmıştı. Buna göre Kağızman'ın Kötek nahiyesinde vukua gelen yer depreminde hasar bildirilen köylerden başka Kızıl ve Enk köyünde altı ahır, iki kom tamamen yıkılmış, on sekiz ev, yirmi iki ahır, on iki oda, üç kom ve altı samanlığın da duvarları çatlamıştı. Kozlu köyünde iki ahır, bir kom, üç samanlık yıkılmış ve iki odanın duvarları çatlamıştı. Çamuş köyünde üç ev, bir oda, iki samanlık yıkılmış ve on sekiz ev ile yirmi iki ahır, on üç oda, üç kom, altı samanlığın duvarları çatlamıştı. Genvan köyünde bir ahır, altı kom yıkılmış, altında üç sığır ve on beş koyun kalarak telef olmuştu. Sevindiren taraf ise can kaybının olmamasıydı. Bu tarih itibarıyla Kötek nahiyesinde şiddetli ve köylerinde ise hafif depremler devam etmekteydi. Çilhane, Purut ve Paslı nahiyelerinde yer sarsıntısından etkilenmiş ev ve samanlıklarda ufak yıkık ve çatlaklıklar meydana gelmiş̧ti. Valilik tarafından açıkta kalan halkın ihtiyaçları için icap eden tedbirler alınmıştı. Ayrıca vaziyet hakkında ilgili makamlara bilgi de verilerek yardım istenmişti. (BCA, Fon No: 30100071198433 lef 4)

Bölgede bu günlerde 8 Nisan 1936 günü saat 9.15'te ve 11.00'da Kağızman'ın Kötek nahiye merkeziyle Yenice köyünde şiddetli bir deprem daha yaşanmıştı. Depremde Kötek'te 4, Yenice'de 3 ev yıkılmış ve Kötek Jandarma Karakolunun duvarları çatlamıştı. İnsan ve hayvan zayiatı yoktu. (BCA, Fon No: 3010007 Yer No: 1198433 lef 1)

\section{Erzincan Tercan Depremi (21 Kasım 1939)}

21 Kasım 1939'da Erzincan Tercan kazasında deprem meydana gelmişti. Deprem Erzincan vilayetinin Merkez, Kemah, Tercan kazalarında hissedildi. Depremde 6 kadın 21 çocuk enkaz altında kalarak yaşamını yitirmiş 56 kişi de yaralanmıştı. Kızılay Genel Merkez depremi haberi alır almaz derhal harekete geçerek depremzedelerin iskânı için 300 çadır ve ilk iaşe yardımı olmak üzere 1.500 lira göndermişti. (Ayın Tarihi, Kasım 1939)

Deprem mahalline o günlerde Erzincan Valisi ve Tercan Kaymakamı giderek gerekli incelemelerde bulunmuştu. Durum tespiti ve alınacak önlemler daha sonra 29 Kasım 1939'da Dâhiliye Vekâletine bildirildi. Buna göre depremin etkili olduğu yerlerde bu tarih itibariyla hasar tespit çalışmaları başlamıştı. Barınmak için ev ve baraka yapılması talimatı verilmiş, açıkta kalan vatandaşlar Kızılay tarafından gönderilen çadırlara yerleştirilmişti. (BCA, Fon No: 301000 Yer No: 11882733 )

Kızılayın yardımları sonraki günlerde de devam etmiş̧i. Kızılaydan 8 Aralık 1939'da Başvekâlete yazılan yazıda Tercan felaketzedeleri için gönderilen 300 çadırdan başka 7 Aralık 
1939 'da 150 çadır ile ahır inşasında kullanılmak üzere 4.000 lira gönderildiği, önceden gönderilen yardımlarla miktarın 7.575 liraya çıktığı bildirilmiştir. (BCA, Fon No: 30100071198433 lef 1)

\section{Erzincan Depremi (27 Aralık 1939)}

Türkiye ve Dünya tarihinin gördüğü en büyük depremlerden biri de şüphesiz 27 Aralık 1939 tarihinde saat iki civarında richter ölçeğine göre 7,9 şiddetinde (http://www.koeri.boun.edu.tr/sismo/2/deprem-bilgileri/buyuk-depremler/, 2020) Erzincan merkezli yaşanan depremdi. Birçok vilayette etkili olan bu depremin ardından Rasathane Müdürlügü bölgede bir inceleme yapmıştı. Depremi mahallinde tetkik etmek üzere o mıntıkaya Rasathane Müdür Muavini Kemal Erkmen gitmiş ve Erzincan, Sivas, Tokat, Samsun, Giresun vilayetleri dâhilinde incelemeler yaptıktan sonra İstanbul'a dönmüştü. Kemal Erkmen, bu inceleme gezisine dair daha sonra Cumhuriyet gazetesine şu açılamada bulunmuştu:

"Ziyaret deprem sahasının genişliği ve mevsim şartlarından dolayı 26 gün sürmüşü. Bu depreme yaptığ tahribat dolaylsiyla Erzincan depremi deniyorsa da sismik nokta-i nazardan buna Kelkit zelzelesi demek daha doğrudur. Bu zelzele için bir merkez değil de bir hat mevzuu bahsolabilir. Uzunluğu 250 km. 'ye varan bu hat Kelkit Vadisi'ni takip ederek Batı'ya doğru, bir taraftan Reşadiye ile Niksar arasında ve Almus, Umala istikametinden Amasya'ya uzanırken, Niksar'ın önünden Kelkit Vadisi'ni takiple Erbaa'dan geçtiği ve Çandır köyünün ilerisine bir kol attı̆̆l, diğer taraftan da Suşehri'nden Doğu'ya doğru ilerlerken Refahiye’nin kuzey köylerini dolaşan bir kolun Erzincan Vadisi'ni katederek Sansa Boğazı'na doğru uzandı̆̆ görülmüş̧ür. Bu tarif ettiğim istikametler üzerinde büyük, küçük birçok çatlaklıklar meydana geçmiştir. Bazl yerlerde bu çatlaklar kilometrelerce uzandığ gibi genişlikleri de bazl yerlerde bir metreyi geçmektedir. Jeolojik tahribat itibarıla hadisenin merkezi sıkleti Suşehri, Koyulhisar, Reşadiye civarındadır." (Cumhuriyet, 12 Şubat 1940)

Bu depremde Erzincan şehrindeki resmi binalar da dâhil olmak üzere tüm binalar tamamen yıkılmıştı. Bu denli şiddette yaşanan deprem, başta Erzincan ve Sivas olmak üzere Amasya, Tokat, Samsun, Ordu, Giresun, Gümüşhane, Yozgat, Malatya ve Tunceli gibi birçok vilayette de hissedilmiş ve yıkıcı sonuçlar doğurmuştu. Bu deprem hakkında yazılacak çok şey olduğu bir gerçektir. Ancak daha önce yapılmış olan yayınlardaki bilgilerle (Yüksel, 2002; Akgün ve Uluğtekin, 2001; Yavuz, 2017) tekrara kaçmama adına biz burada felaketin boyutu ve toplanan yardımları ana hatlarıyla verdikten sonra özellikle 1940- 1950 arasında depremin yaralarını sarmak için Hükûmetin faaliyetleri üzerinde duracağız.

Deprem, Ankara'da haber alınır alınmaz Başvekâlet makamından Dâhiliye ve Hariciye Vekâletleriyle Üçüncü ve Dördüncü Umumi Müfettişliklerle deprem bölgesine komşu tüm vilayetlere aynı gün içerisinde bir yazı gönderilmişti. Yazıda; depremzedelerin barınma ve beslenmeleri, tedavi ve nakilleri gibi hususlarda vali ve kaymakamlarca alınacak tedbirlere bütün devlet daire ve müesseselerinin yardımlarının mecburi olduğu gibi idare amirlerinin bu iş için bütün devlet vasitalarından izin almaya lüzum görmeksizin istifade etmelerinin lüzumlu ve zarurî olduğu bildirilmişti. Yine yazıda yapılacak olan yardımların koordinesi için Dâhiliye ve Sıhhat Vekillerinin 28 Aralık günü sabahtan Sivas'a hareket edecekleri belirtilmişti. (BCA, Fon No: 30100 Yer No: 1211769 lef 2)

Hükûmet depremzedelere yardım için bu ilk tedbirleri alırken Meclis de aynı gün, 27 Aralık'ta deprem özel gündemiyle toplanmıştı. Yapılan toplantıda depremzedelerin acil ihtiyaçlarını karşılamak için Millî Yardım Komitesi kurulmuştu. Komitenin başına da Meclis Başkanı Abdülhalik Renda getirilmişti. (TBMM Zabıt Ceridesi, C. 7, Devre IV, İçtima 1, 1940: 126-128; T.C. Resmî Gazete, 2 Ocak 1940, Sayı: 4399) Meclis Başkanı ve Milli Yardım Komitesi Başkanı Abdülhalik Renda, Komite kurulduktan hemen sonra alınacak tedbirlere dair bir tamim yayımladı. Abdülhalik Renda bu tamimde, felaketzedelerin istırabına ortak olmak için halka ellerinden gelen her türlü yardımı yapmaları konusunda çağrıda bulunmuştu. Bu çağrıyla birlikte Abdülhalik Renda, Reis-i Cumhur İsmet İnönü'nün seri ve etraflı tedbirler alınmasını emrettiği, ilk andan itibaren sıhhi ve 
yiyecek malzemelerinin trenle bölgeye hareket ettirildiği, Mecliste bir Milli Yardım Komitesi kurularak deprem bölgesine hareket ettirildiği ve bütün vilayet ve kazalarda şubeler kurulacağ 1 bilgisini vatandaşla paylaşmıştı. (BCA, Fon No: 30100 Yer No: 1212 768)

Reis-i Cumhur İsmet İnönü de depremin en çok zayiat verdirdiği şehirlerden Erzincan valisine 28 Aralık'ta bir telgraf çekmişti. İnönü telgrafında, Hükûmetin felaketin 1stıraplarını hafifletmek için ne tür tedbirler alınması gerekiyorsa aldığını, Türk halkının Erzincan ile candan alakadar olduğunu ifade ederek (BCA, Fon No: 30100 Yer No: 1212 768) devlet olarak her türlü imkânlarla depremzedelerin yanında olunduğu mesajını vermişti.

Hükûmetin depremzedeler için yaptığı yardım çağrısına ulusal ve yerel basın da destek olmaktaydı. Gazeteler deprem hakkında hem güncel bilgileri okurlarıyla paylaşıyor hem de felaketzedeler için yardım çağrısını yineliyorlardı. (Atay, Ulus, 28 Aralık 1939; Yalçın, Yeni Sabah, 29 Aralık 1939; Nadi, Cumhuriyet, 29 Aralık 1939; Ocakoğlu, İzmir Yeni Asır, 29 Aralık 1939; Aykaç, Cumhuriyet, 30 Aralık 1939; Nadi, Cumhuriyet, 31 Aralık 1939; Benice, Son Telgraf, 31 Aralık 1939; Birgen, Son Posta, 31 Aralık 1939)

Deprem felaketi kıșın en çetin döneminde vuku bulmuştu. Öyle ki 28 Aralık'ta Ankara'dan hareket eden Dâhiliye Vekili Faik Öztrak ve Sıhhat ve İçtimai Muavenet Vekili Ahmet Hulusi Alataş'ın (TBMM Albümü, 2010: 242) içinde bulunduğu tren, yolların karla kaplı olmasından dolayı hareketinden 75 saat sonra ancak 31 Aralık'ta Erzincan'a ulaşabilmişti. Aynı gün, Reis-i Cumhur İsmet İnönü de Erzincan'a gelerek halkın acılarına ortak oldu. Yardım ekipleri bölgeye ulaşır ulaşmaz hemen ilk gün yaralıların tedavisine başladı. Ankara'dan gönderilen ilk yardım ekibi ile beraber Erzurum'dan iki askeri tabip hizmete başladı. Malatya'dan bez fabrikası müdürü reisliğinde bir yardım heyeti geldi. Halka sıcak yemek dağıtımı başladı. Bunlarla birlikte Erzurum Sıhhat Müdürü Dr. Salim başkanlığında bir yardım heyeti kuruldu. Heyetin emrine iki ekip halinde çalışacak 800 asker verildi. Kızılay'dan da ilk yardım olarak 15 bin lira gönderildi. (BCA, Fon No: 301000 Yer No: 119844 11)

Görüldüğü üzere Hükûmet, depremzedelerin bir an önce yardımına koşmak için elinden geleni yapmaya çalışıyordu. Ancak burada daha fazlasını engelleyen iki husus vardı. Bunlardan biri bölgeye yardımları tez zamanda ulaştırmayı engelleyen kış şartları diğeri ise depremin çok sayıda vilayette etkili olmasıydı.

İşte tahmin edilip de tedbir alınamayacak kadar büyük olan bu felakette, depremin hemen ardından en çok can kaybının yaşandığı Erzincan'daki evsiz barksız kalan felaketzedelerin diğer vilayetlerde misafir edilmesi düşünülmüştü. Hükûmetin sevk ve idaresiyle Hatay, İçel, Seyhan, Malatya, Gaziantep, Kayseri, Maraş, İstanbul, Bursa, Manisa, Giresun, Malatya ve Elâzı ğ gibi birçok vilayette depremzedeler misafir edilmişti. (BCA, Fon No: 30100 Yer No: 1216770 lef 8; BCA, Fon No: 30100 Yer No: 1216770 lef 4) Bu şehirler deprem bölgesine yakın ya da demiryolu ulaşımının kolay olduğu şehirlerdi.

Hükûmet, ilk günlerde şimdiye kadar saydığımız tedbirleri alırken bunlara ek olarak depremden etkilenen mıntıkada zarar görenlere yardım yapılması hakkında Meclis'ten 17 Ocak'ta 3773 Sayılı Kanun'u çıkarttırmıştır. Çıkarılan bu Kanun'a göre deprem mıntıkasında, genel bütçeden maaş ve ücret alan memur ve müstahdemlerden yardıma muhtaç olanlara maaş ve ücretleri tutarının iki misli avans desteği verilecekti. Bu durum, emekli ve yetimler için maaş tutarının üç misline kadar belirlenmişti. (T.C. Resmî Gazete, 25 Ocak 1940, Sayı: 4416; TBMM Zabıt Ceridesi, C: 8, Devre VI, İçtima 1, 1940: 68-78) Yine depremzedelere yardım için 28 Şubat 1940 tarih ve 2/12921 sayılı bir Hükûmet kararnamesi de çıkarılmıştı. (T.C. Resmi Gazete, 4 Mart 1940, Sayı: 4449) Kararname'yle depremde evi yıkılan ya da oturulamayacak kadar harap olmuş kişilerin deprem tarihi itibarıla tahakkuk eden kazanç, iktisadî buhran vergileriyle ruhsat ve unvan tezkeresi ve vergi karnesi borçları, hayvanlar, arazi, bina, bina buhran, muamele, muhtelif maddeler istihlâk, veraset ve intikal, yol vergileriyle bilumum belediye vergi ve resimleri ve zamlarının tahsilinden vazgeçilmişti. 
Yine deprem bölgesinde icra takibine düşen borçların takipleri 6 ay müddetle durdurulmuştu. (BCA, Fon No: 301812 Yer No: 9020 4; Kararname No: 2/12962; T.C. Resmi Gazete, 13 Mart 1940, Say1: 4457)

Bu deprem o kadar büyük bir felaketti ki depremin verdirdiği zayiat, üzerinden yaklaşık iki ay geçtikten sonra ancak ortaya çıkmıştı. Deprem bilançosu, resmi makamlardan alınan bilgi doğrultusunda 17 Şubat tarihinde dönem gazetelerinde yayınlanmıştı. Buna göre depremde 32.736 kişi hayatını kaybetmiş 9.402 kişi de yaralanmıştı. (Akşam, 17 Şubat 1940; Cumhuriyet, 17 Şubat 1940) Bu zayiatın illere göre dağılımı aşağıdaki tablodan takip edilebilmektedir.

Tablo 1: 1939 Erzincan Depreminin İllere Göre Zayiat Listesi

\begin{tabular}{|r|c|c|c|}
\hline Sayı & Vilayet & Ölü & Yaralı \\
\hline 1 & Erzincan & 15.740 & 4.117 \\
\hline 2 & Sivas & 7.583 & 1.969 \\
\hline 3 & Tokat & 6.826 & 1.976 \\
\hline 4 & Amasya & 660 & 118 \\
\hline 5 & Giresun & 1.439 & 488 \\
\hline 6 & Ordu & 463 & 488 \\
\hline 7 & Gümüşhane & 233 & 82 \\
\hline 8 & Samsun & 45 & 142 \\
\hline 9 & Trabzon & 3 & 9 \\
\hline 10 & Yozgat & 6 & 6 \\
\hline 11 & Tunceli & 8 & 7 \\
\hline & Toplam & 32.736 & 9.402 \\
\hline
\end{tabular}

Tablodan da görüldüğü üzere deprem birçok vilayette can kaybına yol açmıştı. En çok kayıp ise 15.740 kişi ile Erzincan vilayetinde olmuştu. Bu durum da yukarıda da belirttiğimiz gibi depremde Erzincan şehir merkezindeki binaların neredeyse tamamının yıkılmasından kaynaklanmıştı.

Depremzedeler için ilk günler günü kurtaracak yardımlar yapılırken daha sonra kalıcı yardımlar için Hükûmet kolları sıvamıştı. Bu bağlamda özellikle depremin en çok vurduğu Erzincan şehrinin yeniden imarı konusu öncelikle ele alındı. Hükûmet, yeni Erzincan şehri için eski Erzincan'ın 5,5 kuzeyindeki arazinin kullanılmasına dair 22 Haziran 1940 tarihinde bir kararname çıkardı. (BCA, Fon No: 3018127 Yer No: 9160 16) Kurulacak bu yeni şehrin istimlak işleri ve depremzedelere arsa verilmesi için Meclis'ten 7 Ağustos 1940 tarih ve 3908 sayılı Kanun çıkartıldı. Kanun ile istimlâk işinde belediye idaresi yetkili kılındı. Kanun'a göre depremden zarar görenlerden tapu sahibi olan kişilere bedelsiz arsa verilmesi kabul edilmişti. (TBMM Zabıt Ceridesi, C:13, Devre VI, İçtima 1, 1940: 107-110; T.C. Resmî Gazete, 10 Ağustos 1940, Say1: 4584)

Depremzedelere yurt içi ve yurtdışından yardımlar yaklaşık bir y1l boyunca Milli Yardım Komitesinin koordinesinde toplanmıştı. Komite, toplanan bu yardımları Kızılaya ulaştırmaktaydı. On bir aylık faaliyet sonrasında yardım rakamlarını Meclis'te 27 Kasım 1940 tarihinde Komite namına Seyhan Milletvekili Hilmi Uran açıklamıştı. (TBMM Zabıt Ceridesi, C: 14, Devre 6, İçtima 2, 1940, 60-62, T.C. Resmi Gazete, 30 Kasım 1940, Sayı: 4674) Buna göre yurdun her köşesinden adeta bir hamiyet yarışı halini alan nakdi yardımlar birkaç gün içinde milyonları bulmuş, ayni yardımlar ise vagonları doldurmuştu. (Bu konuda bazı vilayetlerden gelen yardımlar için bkz. BCA, Fon No: 301000 Yer No: 11910 844; BCA, Fon No: 30100 Yer No: 775 482; BCA, Fon No: 30 1000 Yer No: 119844 6; BCA, Fon No: 490100 Yer No: 1582445 1; BCA, Fon No: 301000 Yer No: 11911 844; BCA, Fon No: 490100 Yer No: 15843 462; BCA, Fon No: 490100 Yer No: 1583456 2; BCA, Fon No: 490100 Yer No: 15843 462; BCA, Fon No: 4901007 Yer No: 1584 459 1; BCA, Fon No: 490100 Yer No: 1585470 1) Ülke dâhilinde yardımlar bu şekilde yapılırken 
aynı zamanda birçok yabancı ülkeden de Türk milletinin bu acılı günlerinde cömert yardımlar gelmişti. (BCA, Fon No: 10900 Yer No: 4701360 1)

Hilmi Uran, konuşmasının devamında yurt içi ve yurtdışından gelen yardımların miktarı hakkında bilgi vermişti. Buna göre içeriden ve dışarından yapılan tüm nakdi yardımların toplamı 5.325.870,44 lira olmuştu. Bunun 1.420.727,47 lirası yabancı memleketlerden gelmişti. Geri kalan 3.905.142,97 lirası ise içeriden toplanmıştı. Bu paranın 1.528.755,49 lirası vilâyet merkezlerinden, 1.607.705,89 lirası kaza ve nahiyelerden 768.681,59 lirası da doğrudan doğruya genel merkeze gelen paralarla toplanmıştı. Aynî yardıma gelince, içeriden toplanan gıda maddeleri yardımı 2.177.140 kilo, 97.617 adet, 12.005 paket ve 534 kutu olarak tasnif edilmiști. Bu eșya içerisinde 748.084 kilo buğday, 247.478 kilo bulgur, 78.363 kilo kavurma, 173.646 kilo un, 74.055 kilo üzüm, 8.064 kilo zeytin, 9.044 kilo kuru meyve vesaire vardı. Kullanılacak eşya olarak eşyanın çeşidine göre 3.291 battaniye, 93 çadır, 225 halı, 2.897 kilim, 443 seccade, 4.389 yatak, 6.116 yorgan, 27.554 kilo pamuk vardı. Giyeceğe ait eşya olarak 49.560 çift ayakkabı, 30.773 ceket, 159.439 çamaşır, 80.481 çorap, 27.406 fanila, 57.505 gömlek, 13.531 kazak, 9.155 mintan, 5.978 manto, 10.212 palto, 23.146 pantolon ve 383.187 muhtelif eşya toplanmıştı.

Dışarıdan gelen yardımlar ise şu şekilde idi: 3.600 kilo kaşar, 7.483 sandık balık konservesi, 8.708 sandık et konservesi, 990 sandık öküz eti konservesi, 18 sandık piliç konservesi, 7.979 sandık süt tozu, 2.000 sandık hurma, 58 fiçı limon suyu, 6.806 sandık bisküvi, 3.888 kilo kavurma, 2.998 çadır, 8.000 metre çadır bezi, 36 vagon kereste, 3.642 ton kereste, 11.245 adet oluklu saç, 652 karyola, 29.802 battaniye, 1.864 metre battaniyelik kumaş, 21.512 manto, 42.025 kazak, 20.370 fanila, 16.441 çift ayakkabı. Dışarıdan gelen eşya arasında tıbbi yardımlar da vardı. Bu yardımlar sayı ve nitelik bakımdan önemli yardımlardı.

Hilmi Uran, toplanan iç ve dış yardımları bu şekilde tek tek saydıktan sonra felaketzedelere yardım maksadıyla kurulan Milli Yardım Komitesinin faaliyetlerine artık son verilmesi ve bundan sonra gelecek olan yardımların Kızılay tarafından alınmasına dair Meclise önerge vermişti. Bu istek, Meclis tarafindan kabul edildi. (TBMM Zabıt Ceridesi, C: 14, Devre 6, İçtima 2, 1940: 60-62; T.C. Resmî Gazete, 30 Kasım 1940, Say1: 4674)

Bu rakamlardan da anlaşılacağı üzere gerek Türk milleti gerekse dış dünya bu felâket için adeta birbirleriyle yarışırcasına yardıma koşmuştu. Bu yardımlar yaraların sarılması için elbette ki çok çok önemli idi. Ancak asıl önemli olan bir daha böylesine bir felâketin yaşanmaması için sağlam bina ve şehirlerin yapılması idi. Bu maksatla her ne kadar savaş koşulları yaşanıyor olsa da yeni Erzincan șehri için 1941 yılında bir kanun çıkartılacaktır. Yeni Erzincan şehrinin kurulması ișini üstlenecek olan Erzincan Belediyesine 2 milyon liralık bir borcun verilmesi için 22 Eylül 1941 tarih ve 4126 sayılı Kanun çıkartılacaktır. Kanun tasarısında daha önce 3908 sayılı Kanun ile kurulması kararlaştırılan Erzincan şehrinin alt yapı ve üst yapı çalışmalarına Erzincan Belediyesinin bütçesi yetmeyeceği için bu borcun verilmesinin düşünüldüğü belirtilmişti. (TBMM Zabıt Ceridesi, C. 20, Devre VI, İçtima 2, 1941: 200-205; T.C. Resmî Gazete, 26 Eylül 1941) Kabul edilen Kanun'a göre istenilen 2 milyon liralık borç faizsiz olarak 1946 yılından itibaren 20 senede 20 eşit taksitte hazineye ödenmesi koşuluyla Belediyeye verilmesi kararlaştırılmıştı. (TBMM Zabıt Ceridesi, C: 20, Devre VI, İçtima 2, 1941: 200-205)

Hükûmet bu Kanun'un yanı sıra tüm ülkeyi ilgilendiren 18 Temmuz 1944 tarih ve 4623 sayılı Kanun'u çıkarttırmıştı. Kanun ile deprem öncesi ve sonrası alınacak tedbirler esasa bağlanmıştı. (TBMM Zabit Ceridesi, C: 12, Devre VII, İçtima 1, 1944: 78, 105, 108-114; T.C. Resmî Gazete, 22 Temmuz 1944, Sayı: 5763)

Yeni Erzincan şehri inşası için çalışmalar yürütülürken Kızılay tarafından deprem günlerinde yaptırılan 90 adet pavyonun(TBMM Tutanak Dergisi, C: 20, Dönem 7, Toplantı 3, 1946: 135-139) Erzincan şehrinde tapuları olanlara temlik edilmesi 6 Şubat 1943'te kabul edilmişti. (Ayın Tarihi, Şubat 1943, Sayı: 111) Ancak Erzincan milletvekillerinin seçim bölgesi ziyaretleri için hazırlamış 
oldukları raporlardan hareketle CHP Genel Sekreteri Natıf Kansu tarafindan Başvekile 24 Şubat 1944 tarihinde gönderilen yazıya göre yapılan bu pavyonlardan Erzincanlıların pek de memnun kalmadıklarını görüyoruz. Çünkü Kızılay tarafından pavyonlara yerleştirilen 1.068 aile çok dar mekânlarda yaşamaktaydı. Her aileye neredeyse bir oda düşmekteydi. Bu durum gerek sihhat gerekse ahlak açısından sıkıcı bir durum almıştı. Bir an evvel bu ailelere mesken tedariki yapılması gerekiyordu. (BCA, Fon No: 490100 Yer No: 135 301)

Erzincan'daki inşaatların durumuna ilişkin şikâyetler 1945 yılında da şehri ziyaret eden milletvekillerinin ayrıntılı teftiş raporları ile CHP Genel Sekreterliğine ulaştırılmıştı. (BCA, Fon No: 490100 Yer No: 6471491 lef 72)

Kızılayın yaptırdığı pavyonların durumu bu şekilde iken felaketzedeler için kalıcı konutların istenilen zamanda yapılamaması büyük sorundu. Bu sorunun elbette ki bir sebebi vard1. Bu durumun sebebi, Erzincan Milletvekili Abdülhak Firat'in (TBMM Albümü, 2010: 323) 24 Mayıs 1945 tarihinde Mecliste yaptığı konuşma ile anlaşılacaktı. Fırat'a göre yeni Erzincan şehrinin kurulması için depremin hemen ardından zemin etüt çalışmaları ve inşa planı Hükûmet tarafından onaylanmıştı. Ancak şanssızlık eseri olarak çıkan II. Dünya Harbi işleri yavaşlatmıştı. Harp, fiyatları katladığından dolayı zamanında verilen ödenek ile planlanan inşaat gerçekleştirilememişti. Abdülhak Fırat, duruma ilişkin yapmış olduğu bu açıklamalardan sonra ödeneklerin yetişmemesi sebebiyle inşası duran, tamamlanmayan inşaatlar için ek ödenek konulup konulamayacağını Bayındırlık Bakanı Sırrı Day'a sormuştur. Ancak Bakan, Vekâletin bütçesinin tümü üzerine konuşulan bu tarihli müzâkerede Fırat'ın sorusuna cevap vermemişti. (TBMM Tutanak Dergisi, C: 17, Dönem 7, Toplant1 2, 1945: 346-347)

Abdülhak Fırat Meclis'in 18 Aralık 1945 tarihli görüşmelerinde bu konuyu tekrar gündeme getirmişti. Fırat, deprem sonrasında bir kaç yıl içinde depremzedelere kalıcı konutların verileceği vaat edilmesine rağmen sadece 40 evin temelinin atılarak 26 evin yapıldığını ancak yeni bütçede belediyenin yapacağı bu ev işleriyle alt ve üst yapı için ödenek tahsis edilmediğini bu konuda Hükûmetin ne düşündüğünü Bayındırlık Bakanı Sırrı Day'a sormuştur. (TBMM Tutanak Dergisi, C: 20, Dönem 7, Toplantı 3, 1946: 135-139) 25 Aralık 1945'te Bakan, Abdülhak Firat'ın sorusunu cevaplandırmıştı. Bakana göre 1938 senesinden beri arka arkaya meydana gelen depremler, 17 vilâyeti ilgilendirmiş ve mühim miktarda nüfus ve mal zayiatına sebebiyet vermişti. 1945 yılındaki ödenekle beraber bu tarihe kadar bu işe tahsis edilen para 21.300.000 lirayd1. Bunun 6.500.000 liras1 daha evvel doğrudan doğruya bütçe kanalıyla sarf edilen paraydı. Geri kalanı da Kızılay kanalıyla sarf edilmeye devam edilen parayd1. 6,5 milyon liranın beş milyonu Erzincan ve havalisine sarf edilmişti. Belediyeye daha sonra özel bir kanunla 2 milyon lira ayrıca 1,3 milyon lira da Erzurum belediyesine borç verilmişti. Bakan Meclisi bu şekilde bilgilendirirken şu samimi açıklamayı da sözlerine eklemişti: "Hakikaten bu paraların sarf edildikleri yerlerde bütün hasarların telâfi edildiğine kani değilim. Esasen yapılan müracaatları da tam ve iyi bir şekilde karşılayarak bu tahribatı tamamen telâfi için paramızın kifayet etmeyeceğini takdir buyurursunuz." Bakan, deprem sonrasında Kızılay ile birlikte fertler için ilk yardımlar yapıldıktan sonra bu yeri değişmiş olan şehirlerde bilhassa kamu düzenini, kamu hizmetlerini tesis etmeye çalıştıklarını, yıkılan yerlerde belediyelere, hususi idarelere, mekteplere yardımı esas aldıklarını bilhassa hükûmet konaklarını düzeltmeye çalıştıklarını ifade etmişti. Bu açıklamalardan sonra Bakan şu itirafı da yapmaktan çekinmemiştir: "Elimizdeki imkânlar tam bir kalkınma sağlayacak durumda değildir. Amme hizmetleri için ayırdı̆̆ımız elimizdeki ödenek nispetinde yardım yapacağız." (TBMM Tutanak Dergisi, C: 20, Dönem 7, Toplant1 3, 1946: 402-403)

Erzincan deprem bölgesine yardımların yeterince ulaştırılamadığı konusu, ülkenin çok partili hayata geçişiyle birlikte muhalefetteki Demokrat Partinin lideri Celâl Bayar tarafindan Hükûmete yönelik eleştiri konusu olmuştu. 24 Mart 1948 tarihinde Erzincan'ı ziyaret eden Bayar, depremzedeler için kalıcı konutların yapılarak henüz hak sahiplerine teslim edilmemesinden dolayı Hükûmeti eleştirmişti. (Celal Bayar Diyor ki, 1951: 249) 
Demokrat Parti liderinin Erzincan ziyareti ve ardından Hükûmete yönelik eleştirisinin üzerinden sadece bir hafta geçtikten sonra, 30 Mart'ta Başbakan Hasan Saka Erzincan'ı ziyaret etmişti. Başbakan şehirde yaptığı incelemelerde, depremi müteakip yeni Erzincan'ın kurulduğu yerdeki inşaatları görmüş ve ilgililerden bilgi almıştı. (Ayın Tarihi, 31 Mart 1948)

Bu ziyaretin ardından kısa bir süre sonra Hükûmet, Erzincan depremzedeleri için yaptırılacak meskenler için 6 Temmuz 1948 tarih ve 5243 sayılı Kanun'u çıkarttıracaktı. (TBMM Tutanak Dergisi, C: 12, Dönem VIII, Toplant1 2, 1948: 848-854; T.C. Resmî Gazete, 12 Temmuz 1948, Sayı: 6955) Başbakan Hasan Saka'nın, 21 Haziran 1948 tarihinde yaptırılacak meskenler hakkında Meclise sunduğu kanun tasarısının gerekçesine göre 1940 yılından beri muhtelif zamanlarda vuku bulan deprem ve diğer afetlerden zarar gören bölgelerde yapılan inşaat veya yardımlara harcanmak üzere bütçelere 30 milyon liradan fazla ödenek konmuştu. Ancak Erzincan'da mesken inşaatı kâfi derecede mümkün olamamıştı. Burada halkın ev ihtiyacının banka kredisiyle de karşılanması mümkün olamayacağından mesken işinin devletçe halli zarureti hâsıl olmuştu. Bunun için bütçede "Zelzele bölgelerine yapılacak yardımlar"a ayrılan ödeneğin bundan sonra büyük oranda Erzincan'da ev inşasına tahsisi uygun görülmüştü. Bu maksatla evlerin en uygun tiplerde devletçe inşa olunarak bedeli faizsiz, 20 senede tahsil edilmek üzere hak sahiplerine satılması düşünülmüştü.

Bayındırlık Komisyonunca hazırlanıp 26 Haziran 1948 tarihinde Meclis Başkanlığına sunulan Bayındırlık Komisyonu raporuna göre 1948 yılı Haziran ayına kadar Erzincan şehri için genel bütçeden 2.477.000, Kızılay yardımından 925.000, özel kanunla Erzincan Belediyesine verilecek borç 2.000.000 olmak üzere toplamda 5.402.000 liralık bir yardım yapılmıştı. Bunlardan genel bütçeden yapılan yardımların kamu hizmeti gören daireler inşaatı ile on ikişer odalı dokuz pavyon inşaatına, belediyeye verilen borç para ile gazhane, elektrik santrali, sıhhiye garajı, mezbaha, şoför evi gibi belediye hizmetleri gören inşaatla 19 adedi kerpiç, 16 adedi hımış olmak üzere tek ve çift katlı belediye evleri inşa edilmişti. Kızılay yardımları da muhtelif mevzulara sarf edilmişti. Kızılay tarafindan yapılan pavyonlar geçici Erzincan şehrinde yapılmıştı.

Bayındırlık Komisyonu, yetkili uzman komisyonca yapılan çalışmalara göre Erzincan'da 1.636 binaya ihtiyaç bulunduğu, bu maksada kısa bir zamanda erişebilmek için bundan sonra çok esaslı, programlı ve mümkün olduğu kadar çabuk çalışılması lüzumunu belirtmişti. Rapora göre bu tarihe değin Bayındırlık Bakanlığı, mesken inşaatındaki sürati sağlayabilmek için inşaat aksamı için prefabrik imalâtın tatbiki, memleket dışında buna benzer inşaat için tatbik edilmekte olan demantabl tiplerden faydalanılması ve bunlar için hariçten muhtelif teklifler alınması yoluna gitmiş, bu inşaatın teknik ve iktisadi şartlara göre programlanmasını hedef tutmuştu.

Kanun tasarısı Mecliste 6 Temmuz 1948 tarihinde görüşülmeye başlandı. Tasarı üzerine söz alan DP'li isimlerden Eskişehir Milletvekili Kemal Zeytinoğlu(TBMM Albümü, 2010: 467) ve Kütahya Milletvekili Ahmet Tahtakılıç (TBMM Albümü, 2010: 488) şimdiye kadar depremzedeler için ayrılan paraların iyi kullanılmadığını ve bu Kanun ile tahsis edilen paranın da yeterli olmayacağını söylemişlerdi. Daha sonra söz alan Bayındırlık Bakanı Nihat Erim, (TBMM Albümü, 2010: 484) ayrılan paranın az olduğunu kabulle birlikte devletin günün çok ağır şartları içinde bu parayı ayırdığını söyleyerek paranın daha faydalı kullanılabilmesi için betonarme ev yerine depreme dayanıklı ahşap evler yapımına karar verildiğini, Avusturya'dan yarı imal edilmiş evler alımına dair mutabakat hâsıl olduğunu, bu evlerin Türkiye dâhilinde en ucuz şekilde temin edilebilecek evlerden daha ucuz olduğunu, evlerin sihhi tertibatıyla medeni konforların bütün icaplarılla verileceğini ve son olarak da kışa yetiştirileceğini beyan etmiştir. Bu açıklamaların ardından tasarı oylanmış ve yasalaşmıştı. Kanun'a göre depremde evleri yıkılanlara satılmak üzere ev yaptırılması için yıllık ödeme miktarı 2.000.000 lirayı geçmemek şartıyla 6.000.000 liraya kadar gelecek yıllara sarkacak şekilde geçici yüklenmelere girişmeye Bayındırlık Bakanlığ 1 ve faizleriyle birlikte bu miktarları geçmemek üzere bono çıkarmaya Maliye Bakanlığ yetkili kılınmıştı. Yaptırılacak evlerin tipleri, adedi, satın alma hakkını haiz olanlardan talipliler arasında gözetilecek sıra esasları Bakanlar 
Kurulunca tespit olunacak, inşası tamamlanan evler Hazinece Türkiye Emlâk Kredi Bankasına temlik olunacaktı. Bu evler taliplilerine bedeli faizsiz olarak 20 yılda, 20 eşit taksitte tahsil edilmek üzere satılacaktı.

Kanun'un kabulünden yaklaşık sekiz ay geçtikten sonra yapılacak olan portatif evler hâlâ yapılamamıştı. Bu sebeple konu, Meclisin 26 Şubat 1949 tarihli oturumunda yeniden gündeme geldi. DP Eskişehir Milletvekili Kemal Zeytinoğlu, Hükûmeti "kıştan evvel Erzincan felâketzedelerini barındırmış olacağı ilân edilen portatif evleri bugün biz barındırmak zorunda kalmışızdır" sözleri ile eleştirmiştir. (TBMM Tutanak Dergisi, C: 16, Dönem 8, Toplantı 3, 1949: 713) Erzincan Milletvekili Abdülhak Fırat bölge milletvekili olarak Kemal Zeytinoğlu'nun bu eleştirisini doğru bulmamış ve Erzincan evlerinin tüm beton inşaatlarının yapıldığını fakat oraya takılacak hazır evlerin dışarıdan getirileceği için birtakım kayıt ve şartlara tâbi olduğunu söylemiştir. (TBMM Tutanak Dergisi, C: 16, Dönem 8, Toplant1 3, 1949: 725-726)

Abdülhak Fırat hatırlanacağı üzere 1945 yılından beri meselenin yakın takipçisiydi. Kendisi o tarihten beri Hükûmeti Erzincan'a yapılacak olan evler konusunda sıkıştırmaktaydı. Ancak DP'li bir milletvekilinin Hükûmeti eleştirmesi karşısında kendi partisinin kurduğu Hükûmeti savunmuştu.

Bu gelişmeden bir y1l sonra sorunlar hâlâ çözülememiş vaziyette beklemekteydi. 20 Şubat 1950 tarihli Meclis görüşmelerinde Eskişehir Milletvekili Kemal Zeytinoğlu, aradan on seneden fazla bir zaman geçtiği halde felâketzede bir şehri imara ve mustaripleri teskine Hükûmetin muvaffak olamadığını, Avusturya'dan satın alınan altı yüz takma evin maliyetlerinin çok yüksek olduğunu bunları sahiplerine borçlandırmak suretiyle devretmek imkânı kalmadığını, Avusturya'dan tütün karşıllı̆g getirilip de orada kurulan bu evlerin yerinde ora rayicine göre pahalı olduğundan hareketle bu evlerin mahallî rayiçlerine göre yeniden maliyetinin hesap edilmesi gerektiğini belirtmişti. Yine maliyetin yarısının devlet, diğer yarısının da Erzincanlılara faizsiz ve uzun vadelerle ödettirmek suretiyle hal yoluna konulmasını arzu etmişti. Kemal Zeytinoğlu'nun bu eleştirilerine karşı cevap veren ilk isim CHP Giresun Milletvekili İsmail Sabuncu (TBMM Albümü, 2010: 469) olmuştu. Sabuncu, evlerin bedeli tütün takası ile gelmesi dolayısıyla belki biraz pahalıya mal olmuş olabileceğini fakat en pahalısının 11 bin lira ve dört oda olarak memleketin diğer vilâyetlerinde de böyle dört oda ve bu şartlar altında yapılmak imkânı olsa, herkesin bu fiyatı makul karşılayacağını söylemiştir. Sabuncu, konuşmasının devamında bu şartlar altında Kemal Zeytinoğlu'nun meseleyi propaganda mahiyetinde Hükûmetin hiçbir şey yapmamış gibi gösterme çabası içerisinde olduğunu söylemiştir. 21 Şubat 1950 tarihli görüşmelerde Kemal Zeytinoğlu bu ithamı kabul etmeyerek tarafsız bir mühendisler heyeti teşkil edilerek oraya gönderilmesini teklif etmiştir. Bu tarihteki Bayındırlık Bakanı Şevket Adalan, (TBMM Albümü, 2010: 477) bu evlerin pahalı olduğu ve kimsenin satın almak istemediği iddialarına karşılık olarak şu açıklamada bulunmuştu: "Bence bu evleri getirmekle ve yapmakla hayırlı bir iş yaptığımıza kaniyiz. Biz şimdiye kadar 600 ev yapabildik. Bunun dışında 70 eve daha talip bulunduğu için yeniden 70 ev yaptıracağız. Binaenaleyh kendilerinin dedikleri gibi bu evlerin taliplerine devredilemediği yolundaki ifadeleri doğru değildir. Erzincan'da şimdiye kadar 600 ev yapılmış, bunların 292'si 4 odall, 250'si 3 odal ve 58'i 2 odalıdir. Sirastyla bunların maliyetleri 11.222, 7.865 ve 6.961 liradir. Bu maliyetler geçicidir. 70 evi de inşa ettikten sonra bunların hesabını yeni baştan yapıp hakiki maliyetlerini tespit edeceğiz. Bunların metrekareleri sirasiyla 110, 132, 148 liradır. (...) Erzincan rayici üzerinden bu evlerin hesaplarını yaptırdık. Yapı işleri reisliğinin bana verdiği bu hesaplara göre ĕger biz bu evleri hariçten getirtmemiş olsaydık mahallî rayiçlere göre ve yerli malzeme ile dört odalı evleri 14.712, üç odalı evleri 10.606 ve iki odal evleri de 8.865 liraya mal edecektik. (...) Bütün bu verdiğim hesaplardan anlaşılacă̆ı gibi bu evler pahalıya mal edilmemiş, bu evleri hariçten getirmekle, hatalı bir hareket yapılmamış, bilâkis hayırlı bir iş olmuştur." (TBMM Tutanak Dergisi, C: 24, Dönem 8, Toplantı 4, $1950,958)$ 
Erzincan depremzedeleri için bu dönemde CHP Hükûmetlerinin yaptı̆̆ 1 son iki işten biri, 5586 ve 4126 sayıl Kanunlarla Erzincan ve Erzurum Belediyelerine verilen toplamda 3.300.000 liralık borcun belediyelerin ödeyecek gücünün olmamasından dolayı silinmesi olmuştur. (TBMM Tutanak Dergisi, C: 25, Dönem 8, 1950: 202; T.C. Resmî Gazete, 10 Mart 1950, Sayı: 7453) Bir diğeri ise Erzincan'da yaptırılacak meskenler hakkındaki 5243 sayılı Kanun'da bazı değişiklikler yapılmasına ve bu Kanun'a bazı hükümler eklenmesine dair 13 Mart 1950 tarih ve 5594 sayılı Kanun idi. Bu Kanun'la depremzedeler için yapılacak olan konutların arsalarının kamulaştırma işlemleri ile konutların temlik meselelerinde yaşanan sorunlar çözüme kavuşturulmuştu. (T.C. Resmî Gazete, 18 Mart 1950, Sayı: 7460)

Görüldüğü üzere 1939 yılında yaşanan deprem felâketi, üzerinden 10 yıldan fazla bir süre geçtiği hâlde 1950 yılında hâlâ ülke gündemindedir. Gerçi bu felâket öylesine küçük çaplı, altından kolaylıkla kalkılacak bir felâket de değildi. Cumhuriyet tarihinin hatta insanlığın bu tarihe kadar gördüğü en büyük felâketlerinden biri idi. Devrin CHP iktidarı deprem felâketi yaşanır yaşanmaz hemen ülkenin tüm imkânlarını seferber etmişti. Bu seferberliğe Mecliste kurulan Millî Yardım Komitesi ön ayak olmuştu. Komitenin koordinesinde felaketzedelerin acılarını sarmak için yurt içinden ve yurt dışından gönderilen ayni ve nakdi yardımlar Kızılay vasıtasıyla hak sahiplerine ulaştırılmıştı. Ancak depremzedelerin kalıcı konutlara sahip olması hususunda istenilen düzeyde başarı sağlanamamıştır. Gerçi bunda büyük ölçüde II. Dünya Harbi koşulları etkili olmuştu. Savaştan dolayı inşaatta kullanılacak olan malzeme tedarikinde yaşanan sıkıntılar ve de o yılların ekonomik imkânları depremzedelerin bir an önce kalıcı konutlara sahip olabilmesinin önündeki en büyük iki engeldi.

\section{Erzincan Depremi (12 Kasım 1941)}

1939 yılındaki büyük felaketin üzerinden bir y1l geçmemişti ki Erzincan bir felaketi daha yaşadi.

CHP Erzincan İdare Heyeti Reisi Fevzi Ulusoy'un CHP Genel Sekreterliğine 12 Kasım 1941 'de "acele" olarak çektiği telgrafa göre Erzincan'da 12 Kasım günü saat 12.10 'da 25 saniye süren şiddetli bir yer sarsıntısı olmuştu. Yaşanan depremde nüfusça zayiat olmuştu. Ancak hemen o gün çekilen telgrafta can kaybının miktarı hakkına bir bilgi verilememiş, tespit çalışmalarının sürdüğü notu düşülmüştü. Mal kaybı olarak ilk gün verilen bilgi, Halkevi binasının yıkıldığı ancak burada bulunan talebenin can kaybının olmadığ şeklinde idi. (BCA, Fon No: 490100 Yer No: 15834552 lef 14) CHP Genel Sekreterliği durumdan Kızılay Genel Merkezini haberdar etmiş ve gereken yardımların yapılmasını istemişti. (BCA, Fon No: 490100 Yer No: 15834552 lef 13) Kızılay Genel Merkezi istenen yardımları bölgeye ulaştırmış ve bu konu hakkında CHP Genel Sekreterliğine 19 Kasım'da bilgi vermişti. Buna göre Erzincan vilayetinin istediği 400 çadır ve muhtelif cins ve miktarda ilaç ve pansuman malzemesi ile yatak, yatak çarşafi, yastık, battaniye gibi eşya ve levazım, kısmen Erzurum'daki Kızılay Transit Deposu'ndan ve kısmen de Etimesgut'taki Kizılay ambarlarından gönderilmek suretiyle ilk yardım ihtiyaçları karşılanmıştı. Ayrıca Erzurum deposundaki kalan çadırların da Erzincan'a gönderilmesi mahalline bildirilmişti.

Bununla birlikte Erzurum Kızılay Merkezince Erzincan'a bir hastabakıcı, hemşire ve iki pansumancı gönderilerek yaralıların tedavilerinde yardımcı vazife almaları temin olunmakla beraber bu tarihe kadar Erzincan Kızılay Hastanesine gelen yaralıların iaşe ve tedavileri de yapılmaktaydı. Yine Kızılay Cemiyeti Reisi ihtiyaç halinde mahallinden istenmesi durumunda gerekli yardımların yapılacağını da yazısına eklemişti. (BCA, Fon No: 490100 Yer No: 15834552 lef 11)

Yukarıda depremin ilk günü Parti merkezine çekilen telgraftan depremde ne kadar can ve mal kaybının olduğuna dair bir bilgi verilmemiş olsa da depremden 8 gün sonra mahallinden 400 kadar çadırın istendiği bilgisinden hareketle bu depremde ciddi anlamda bir can ve mal kaybının olduğunu söyleyebiliriz. 


\section{Van Erciş Depremi (11 Eylül 1941)}

11 Eylül 1941 tarihinde Van vilâyeti Erciş kazası Kocapınar nahiyesi merkezli bir deprem meydana gelmişti. Deprem Erciş kadar olmasa da Ağrı vilayetinde de hissedilmişti. İlk andan itibaren depremzedelerin acil ihtiyaçları için mülkî ve askerî makamlar ile Kızılay hemen harekete geçmişti. Depremde 12 Eylül itibarıla Kocapınar nahiyesine bağlı 30 köyde ve Merkez nahiyeye bağl1 Aksıraf-Partak, Anzaf, Cançank, Pür, Tarhatan köylerinde 90 vatandaş ölü olarak enkaz altından çıkarılmıştı. Açıkta kalan halk için hemen ilk gün Van Valiliğince 500 çadır ile 5.000 lira yardım gönderilmiş ve yaralıların tespit ve tedavisine başlanmıştı. (BCA, Fon No: 3010007119848 18) Enkaz kaldırma çalışmaların sonunda can kaybının ne kadar olduğuna dair elimizde herhangi bir bilgi yoktur. Ancak kuvvetle muhtemel yukarıda zikrettiğimiz rakamdan daha fazla kişi bu deprem felaketinde hayatını kaybetmişti.

Depremin yaralarını sarmak için Genelkurmay da harekete geçmişti. Mareşal Fevzi Çakmak, Doğu vilayetlerinde depremden zarar görenlere çadır, doktor, erzak yardımı gönderildiğini Başvekâlete 12 Eylül 1941'de bildirmişti. (BCA, Fon No: 301000 Yer No: 119848 19)

Kızılay ise 11 Eylül 1941 'de bin lira para ve depremzedelerin geçici iskânları için Erzurum'dan 500 çadır, Erzincan'dan 80 çadır ayrıca Diyarbakır Kızılay Merkezinden de bin lira para göndermişti. Kızılayın yardımları sonraki günlerde de devam etmişti. 17 Eylül tarihli bir belgeden anlaşıldığına göre bu güne kadar Kızılay tarafından yapılan yardımların nakdi miktarı 3.350 lira olmuştu. Bu nakdi yardım haricinde ayrıca yeterli miktarda ayni ve sıhhi yardım da yapılmıştı. (BCA, Fon No: 301000 Yer No: 179235 4; BCA, Fon No: 490100 Yer No: 1582445 1; BCA, Fon No: 3010007120849 1; BCA, Fon No: 490100 Yer No: 1582445 2)

\section{Van Depremleri (1945-1946)}

1945 yılı Van için tam bir kâbus y1lı olmuştu. 28 Haziran'da başlayan Van depremleri aralıksız yedi ay boyunca devam etmişti. Sürekli yaşanan bu depremleri incelemek için Başvekil Şükrü Saraçoğlu'nun emri üzerine bir heyet oluşturulmuştu. Heyette İstanbul Üniversitesi Jeoloji Enstitüsünden Ord. Prof. Dr. Hamit Nafiz Pamir, MTA. Enstitüsü jeologlarından Dr. Lahn ve Bayındırlık Bakanlığı Yapı ve İmar İşleri Fen Heyeti Müdürü Fikri Alpay vardı. Heyetin raporunu Bayındırlık Bakanı 2 Ağustos 1945'te Başvekâlete sundu. Rapora göre 28 Haziran'da başlayıp ara ara 24 Temmuz 1945 'e kadar devam eden depremler tektonik kaynaklı idi. Şiddeti ise 6 seviyesindeydi. Deprem bilhassa Yedikilise, Kurubaş, Keşişoğlu, Sivekerek, Pertik köylerinde tahribat yapmıştı. Deprem ayrıca Van merkezinde, Şoşan ve Sevistan köylerinde hissedilmişti. Ancak hasar nispeten az olmuş, duvarlar çatlamış ve bazı bacalar devrilmişti. Depremin en çok tahribat1 Pertek köyündeydi.

Heyet, bölgede önceden bu dereceden daha şiddetli bir deprem yaşanıp yaşanmadığı bilgisi olmadığından dolayı öneri olarak, şimdiden şehirlerin ve köylerin yerlerini değiştirmek gibi tedbirlere lüzum görmemişti. Heyete göre hasar görmüş ve çatlamış olan yapıların tamir ve takviye edilerek içlerine girilebilirdi. $\mathrm{Bu}$ tür tamir ve takviye işlerinin ileride yaşanacak muhtemel sarsıntılarda yapıların yıkılmaması için hemen yapılması gerekliydi. Rapor tarihinde hasar ve zayiat, bazı bacaların devrilmesi ve duvarların çatlaması gibi nispeten hafif tahribattı. Bayındırlık Bakanı, raporu bu şekilde Başvekâlete özetledikten sonra ilk yardımlar olarak şimdilik Van deprem bölgesine Kızılaydan 75, Millî Savunma Bakanlığından yeterli miktarda çadır ile Bayındırlık Bakanlığı tarafından 5 ton çivi ile 4.000 lira gönderildiğini bildirmişti. (BCA, Fon No: 301000 Yer No: 120 85012 lef 8 )

Rapor sonrasında depremler bölgede devam etmişti. 20 Kasım 1945 tarihinde vuku bulan depremde bir kişi ölürken 3 kişi de yaralanmıştı. (BCA, Fon No: 301000 Yer No: 12085012 lef 6) 
Aylarca süren bu depremlerin sonuçlarını ve alınan tedbirleri Van CHP İl İdare Kurulu Başkanı Muzaffer Koçak'ın CHP Genel Sekreterliğine gönderdiği 4 Şubat 1946 tarihli rapordan anliyoruz. Rapora göre 7 aydan beri hemen her gün muhtelif şiddette devam eden depremde; devlet dairelerinin ya hepsi yıkılmış ya da bunlar içinde oturulamayacak hale düşmüştü. Bütün daireler barakada iş görmekteydi. İlkokullar ve ortaokullarda da yıkım olmuştu. Bu tarihte baraka yapılmaya devam ediyordu. Doğumevi ve askeri hastaneler ya kısmen yıkılmış ya da yıkılma tehlikesinden dolayı boşaltılmıştı. Hastalar baraka veya bodrumlarda barındırılmaktaydı. Özel binaların \% 80'i ya yıkılmış ya da yıktırılmıştı. Baraka ve çadırlarda yatılmaktaydı. Bir kısım memur ve subay da aynı durumdaydı. Yapılacak tamiratla, içinde oturulabilecek resmi binalardan yalnız vali konağı ile halkevi binası ve özel kişilere ait yüzü geçmeyen ev vard1.

Yardım olarak Kızılay, Bayındırlık Bakanlığı, Birinci Genel Müfettişlik, bazı il ve ilçelerden toplamda 180 bin lira, 100 metreküp kereste, 10 ton çivi ve bin çadır gelmişti. Bu paradan Merkez'de iki bin muhtaç nüfusa beşer lira hesabıyla on bin lira verilmişti. 3 bin lira da zarar gören köylere verilmek üzereydi. 30 bin liralık kereste satın alınarak köylülere ve Merkez'de muhtaç durumda olanlara dağıtılmıştı. 60 bin lira hükûmet daireleri ve bir kısım memur barakalarına verilmişti. (BCA, Fon No: 490100 Yer No: 15864711 lef 3-5; BCA, Fon No: 301000 Yer No: 120850 14)

$\mathrm{Bu}$ depremde zarar görenler daha sonra mükellef oldukları çeșitli vergilerden de muaf olmuşlardı. 20 Kasım 1945'te meydana gelen depremde zarar gören 511 mükellefin 1939-1945 yıllarına ait bina vergisinden 6.873 lira 15 kuruş, 457 mükellefin buhran vergisinden 1.576 lira 51 kuruş, 448 mükellefin müdafaa vergisinden 1.425 lira 35 kuruş, 566 mükellefin arazi vergisinden 10.343 lira 22 kuruş ve 497 mükellefin yol vergisinden 9.830 lira 54 kuruş olmak üzere toplam 30.489 lira 77 kuruştan ibaret vergilerinin silinmesi Bakanlar Kurulunca 2 Ekim 1948'de kararlaştırılmıştı. (BCA, Fon No: 301812 Yer No: 11764 6)

\section{Muş Varto Depremi (31 Mayıs 1946)}

31 Mayıs 1946'da Muş Varto'da deprem olmuştu. Depremden Varto Merkez ve köyleri etkilendi.

Depremin Ankara'da duyulmasının ardından hemen İçişleri Bakanlığı yardım için harekete geçmişti. (BCA, Fon No: 301000 Yer No: 120850 15) 3 Haziran 1946 tarihinde deprem hakkında Meclisi bilgilendiren İçişleri Bakanı Hilmi Uran, bu tarih itibarıyla depremde 390 kişinin hayatını kaybettiği ve 100 kişinin de yaralandığı bilgisini paylaşmıştı. Uran, konuşmasında depremin verdiği maddi hasar ve depremzedelere yapılan yardımlardan da bahsetmişti. Buna göre Varto merkezinde 120 ev, 15 dükkân, 1 cami; köylerde de 79 ev yıkılmıştı. Bu tarihte Varto 895 nüfuslu ve 141 haneli bir kasaba idi. Bu durum dikkate alındığında kayıp gerçekten Varto için çok büyüktü. Depremin ilk haberinin alınmasından 3 Haziran tarihine kadar Van'dan 150 çadır, Bitlis'ten 400 çadır, Erzurum'dan 250 çadır olmak üzere deprem mahalline toplamda 800 çadır gönderilmişti. İaşe maddesi olarak da Erzurum 'dan 1.000 kilo ekmek, 50 kilo kavurma, 50 kilo zeytin, elli kilo peynir; Bitlis'ten ve Van'dan da ekmek yollanmıştı. Erzurum'dan ayrıca kazma, kürek, fener, keser, testere ve sedyeler gönderilmişti. Kızılay para yardımı olarak deprem mahalline 10 bin lira gönderdiği gibi nakliyede harcanılmak üzere de Erzurum'a 2.000, Umumi Müfettişlik emrine 5.000, Karlıva'ya 1.000, Bitlis'e 1.000 lira gönderilmişti. Ayrıca 14.350 lira da 50 ton buğday bedeli olarak ofise verilmek üzere yollanmıştı. Kızılay tarafından 400 kişilik pansuman malzemesi, Diyarbakır'dan 4 kişilik bir ekiple bir hastane çadırı, Hınıs'tan, Van'dan, Bitlis'ten kâfi miktarda sıhhi malzeme gönderilmişti. Hınıs'tan iki doktor, Ankara'dan bir operatörle iki pansumanc1, Diyarbakır'dan bir doktor, Erzurum ve Bitlis'ten birer sağlık memuru yollanmıştı. Muş Valisi yanında jandarma kumandanı, nafia ve sağlık müdürleri olduğu halde köyleri taramak üzere bölgeye gitmişti. Uran, konuşmasının sonunda bu yardımların daha da genişletileceğini söylemiştir. (TBMM Tutanak Dergisi, C: 24, Dönem 7, Toplantı 3, Ankara 1946: 3-4) 
Dönem gazetelerinden Ulus gazetesi 6 Haziran tarihinde Hınıs'taki özel muhabirinden aldığ 1 bilgilere göre bu çevrede 2.000 evin yıkıldığını, 813 kişinin öldüğünü ve 200 kişinin de yaralandığını okurlarına servis etmişti. Hınıs'taki depremde de 48 ev yıkılmıştı. Bütün bölge halkı depremzedelere yardım için harekete geçmişti. Hınıs'tan ilk parti yardım olarak 1.000 lira ve 11 top bez gönderilmişti. Depreme uzak olan yerlerden de yardımlar gelmekteydi. Örneğin Karadeniz Ereğli'sinde yardım için Kaymakam başkanlığında bir komisyon kurulmuştu. Bu komisyon ilk yardım olarak depremzedelere 580 lira göndermişti. (Ulus, 7 Haziran 1946)

Yine o günlerde depremi mahallinde görmek için Sağlık ve Sosyal Yardım ve Bayındırlık Bakanları bölgeye gitmişti. Bu Bakanlar yıkılan 1.991 evden açıkta kalan nüfus için Maliyeden acele 500.000 liralık yardım istemişlerdi. Maliye Bakanı 1946 yılı Bütçe Kanunu'ndaki yardım ödeneği Kızılaya devredildiği ve de Meclisin tatilde olması sebebiyle bütçeden ödeme yapılamayacağını ancak aciliyetinden dolayı Kızılay Derneği marifetiyle bu yardımın yapılması ve Meclisin ilk toplantısında alınacak ek ödeneklerle Derneğe devrin yapılmasının muvafik olduğunu Başbakanlığa 15 Haziran 1946'da bildirmişti. (BCA, Fon No: 301000 Yer No: 120850 16) Böylelikle sorun çözülmüş oluyordu. Zira kayıplar ilk günlerdeki rakamlardan çok fazlaydı. Deprem 5,7 şiddetinde yaşanmış ama kayıpları oldukça fazla olmuştu. Meydana gelen depremdeki can kaybı daha sonraki yeni bilgiler doğrultusunda 839 kişiye ulaşmıştı. (www.varto.gov.tr/ilcemiz-genel-bilgiler, 2020)

Hükûmet, depremden zarar görenlerin devlete olan borçlarını silerek depremzedeleri bu şekilde de rahatlatmaya çalışmıştı. Depremden \% 100 zarar gören, toplam 71 köydeki 1.140 mükellefin 1941-1946 y1llarına ait yol, arazi, bina, buhran ve müdafaa vergisinden olmak üzere toplam 23.958 lira vergi borçlarının silinmesi Bakanlar Kurulunca 22 Mart 1948'de 4623 sayılı Kanun'un 27 maddesine göre kabul edilmişti. (BCA, Fon No: 301812 Yer No: 11622 2) Yine 21 Kasım 1949'da ise 3.833 mükellefe ait ruhsat tezkeresi, karne harcı, kazanç vergisi, hayvanlar vergisi, mahkeme harc1, ceza zamları, veraset ve intikal vergisi fevkalade zam, buhran vergisi olmak üzere toplam 48.698,84 lira olan vergi borçlarının affedilmesi de kabul edilmişti. (BCA, Fon No: 30181 2 Yer No: 120824 )

\section{Bingöl Depremi (17 Ağustos 1949)}

17 Ağustos 1949 tarihinde Bingöl merkezli bir deprem yaşandı. Bu depremden Erzurum, Çat, Bingöl, Karlıova, Kiğı, Erzincan, Tercan ve Nazımiye etkilenmişti.

19 Ağustos'a kadar deprem bölgesinden alınan bilgiler ile yapılan ve yapılması istenen yardımları İçişleri Bakanı, Başbakanlığa gönderdiği yazıda bildirmişti. Yazıya göre Karlıova'da 163 ölü ve 100'e yakın yaralı, Kiğı'da ise 83 ölü ve 100 'den fazla yaralı vardı. Bununla birlikte Karlıova'da 400, Kiğı'da 500'den fazla ev tamamen yıkılmış, birçok ev de oturulamaz hale gelmişti. Yaralılar çevre hastanelere yetiştirilirken en az ellişer yataklı 2 seyyar hastanenin kurulması ve vilayete gıda için 20.000 lirayla çadır ve gıda malzemelerinin gönderilmesi gerektiği bildirilmişti. (BCA, Fon No: 301000 Yer No: 120850 18)

$\mathrm{Bu}$ arada meydana gelen depremden etkilenen ve muhtaç olanlara devlet ormanlarından parasız kerestelik ağaç verilmesi Bakanlar Kurulunca 24 Ağustos 1949'da kararlaştırılmıştı. (BCA, Fon No: 301812 Yer No: 12064 13)

Bingöl'de yaralar sarılmaya çalışılırken 24-28 Ağustos tarihlerinde artçı depremler meydana gelmişti. Kiğ 1 Belediye Başkanı Halil Abusoğlu ve arkadaşları tarafından Cumhurbaşkanlığına 27 Ağustos 1949 tarihli bir telgraf gönderilmişti. Bu telgrafta Kiğı'da bu tarihte kadar devam eden depremde 120 kişinin öldüğü ve çok sayıda yaralının olduğu, oturulacak bina kalmadığından Eylül ayının ortasına kadar bir an önce Kiğı'ya yardımların ulaştırılması istenmişti. (BCA, Fon No: 3010 00 Yer No: 12085021 lef 2-3) İstek Cumhurbaşkanlığı tarafından Başbakanlığa gönderilmişti. Başbakanlık da 31 Ağustos tarihinde talebin incelenerek gereğinin bir an önce yapılması için 
Bayındırlık ve İçişleri Bakanlıklarına talimat vermişti. (BCA, Fon No: 301000 Yer No: 120850 21 lef 1)

Bu yazı üzerine İçişleri Bakanı deprem bölgesine gitmişti. Bakan, 3 Eylül 1949'da ziyareti kapsamında uğradığı Erzurum'da halka hitap etmişti. Bakan konuşmasında deprem felâketzedelerine Hükûmetin "kış gelmeden kendilerinin bir dam altına yerleştirilmelerini sağlayacak tedbirleri almak için geldiklerini" söylemişti. (Ayın Tarihi, 3 Eylül 1949) Bu örnekte de görüldüğü üzere devlet, felaketzede vatandaşlarının yaralarını sarmak için en düzey kurumlarıyla bu işin takipçisi olmuştu.

Bingöl depreminden sonra depremzedelerin ev yardımı için devletin hane ya da kişi başına verdiği paranın Karlıova için yetersiz olduğuna dair Karlıova CHP İlçe Başkanı Hasan Lütfi Atlı 30 Eylül 1949'da CHP Genel Sekreterliğine bir telgraf çekerek yardımların arttırılmasını talep etmişti. (BCA, Fon No: 490100 Yer No: 15824492 lef 7-11) Bu istek Parti yönetimi tarafından Başbakan Yardımcısı Nihat Erim'e gönderilmişti. (BCA, Fon No: 490100 Yer No: 15824492 lef 4) Buradan yazı, ilgili Bayındırlık Bakanlığına gönderilmişti. Bakanlığın verdiği cevap telgraf sahibinin bilgilendirilmesi maksadıyla 9 Nisan 1950'de Parti yönetimince Bingöl Parti Başkanlığına gönderilmişti. (BCA, Fon No: 490100 Yer No: 15824492 lef 1) Buna göre Bingöl'de deprem mıntıkasındaki felaketzedelere gerek acil yardım gerekse yıkılan evlerini yapmaları için ayni ve nakdi olmak üzere bu tarihe kadar yapılan yardımların toplamı 700 bin lirayı bulmuştu. Bölgedeki evlerin yapı malzemesi göz önünde bulundurularak ve İçişleri Bakanı Emin Erişirgil ve Bingöl Valisi ile müşterek olarak hazırlanan raporda merkezde 500, köylerde 300 lira hane başına nakdi yardım dağıtılmıştır. Bununla birlikte duvarından bir kaç taşı düşen ya da birkaç ağacı kırılan vatandaşa da 20-30 lira verilmiştir. Bunlardan başka Karlıova bölgesine 990 kazma kürek, 6150 kg. çivi, 108 metreküp meşe ağacı sevk edilmiş her müracaat eden vatandaşa ihtiyacı oranında dağıtılmıştı. Yine bölgeye muhtelif vilayetlerden yol masrafları ödenerek yevmiyeleri kendileri tarafindan ödenmek suretiyle ustalar gönderilmişti. Ayrıca bir bölük asker de köy köy dolaşarak ustalık ve amelelik yapmak suretiyle felaketzede vatandaşların evlerini yapmalarına yardım etmiş̧i.

Neticede 425 yıkılan, 875 hasar gören eve karşılık 425 ev yeniden inşa edilmiş, 1.497 ev ve ahır da tamir edilmiştir. Tüm bu işlerin bitip herkesin kıştan evvel evine girdiği, Bingöl Valiliğinin 12 Kasım 1949 tarihli yazısından anlaşılmıştı.

Bingöl Valiliği bu yardımlardan başka Bingöl vilayetine yapılan diğer yardımlar hakkında da bilgi vermişti. Buna göre bütün mıntıkaya yapılan 285.000 liralık acil yardımdan da depremzedelere yiyecek ve giyecek maddeleri verilmişti. Yine acil yardım olarak 1.200 çuval un Karlıova'ya gönderilmiş, maliyet fiyatı üzerinden isteyenlere verilmişti. 200 tonu Genç'ten, 300 tonu Erzurum'dan kendi imkânları ile almak üzere halka buğday verilmişti.

Karlıova'daki resmi binaların bazıları ciddi hasar görmüştü. Özel idare binası, halkevi olarak kullanılan Belediyenin kârgir binası yeniden yapılmış ve bir de ahşap ilkokul inşa edilmişti. Belediyenin, özel idarenin işgal ettikleri binalarla jandarma karakolları tamir edilmişti. Yine ikişer odalı 8 lojman yapılmış ve memurlara tahsis edilmişti. Bütün bu resmi binalar ve memur evleri için 220 metreküp kereste, 3 ton çivi ve 74.386 lira sarf edilmişti. (BCA, Fon No: 490100 Yer No: 1582 4492 lef 2-3)

Bingöl merkezli yaşanan depremin yaralarının ne derece sarıldığını, 1950 yılı Bütçe Kanunu üzerine 11 Kasım 1949 tarihli Meclis görüşmeleri sırasında CHP Erzurum Milletvekili General Vehbi Kocagüney'in Bayındırlık Bakanı Şevket Adalan'ın cevaplandırması isteği üzerine verdiği soru önergesinden anlıyoruz. Bakan, yer sarsıntısından en fazla zarar gören, Karlıova ve Kiğı ilçeleri ile Erzurum ilinin Çat bucağında halkın kıştan evvel barındırılması için gereken bütün tedbirlerin alındığını, Kasım ayının sonuna kadar bütün işlerin tamamlanmış olacağını bildirmişti. Bakanın verdiği bilgilere göre acil yardımlar karşılığı olarak harcanan 256 bin lira dışında yıkılan veya hasar gören binaların tamir ve inşası için Erzurum iline 135.000 lira, Bingöl iline 350.000 lira para yardımı yapılmıştı. Bakan ayrıca Erzurum'a 5 ton ve Bingöl'e 15 ton çivi sevk edilerek Orman Kanunu'na 
göre halkın meskenleri için lüzumlu kerestenin parasız olarak sağlandığını, gönderilen paralardan 400 küsur bin liranın da harcandığını sözlerine eklemişti.

Bakan'ın ardından söz alan soru sahibi Vehbi Kocagüney, verdiği izahattan dolayı Bakan'a teşekkürlerini iletirken depremin Erzurum'daki etkisi ve Hükûmetin yardımlarına dair açıklamalarda bulunmuştu. O'na göre depremde yalnız Erzurum ili Çat bucağında 31 köy hasara uğramış, iki köy tamamen yıkılmıştı. Felâketin meydana gelmesini müteakip Hükûmetin şefkatli eli felaketzedelere çok çabuk yetişmişti. Erzurum ili vakayı müteakip geceden bir sağlık ekibi çıkarmış, felakete uğrayan köylere hekimler göndermişti. Ertesi gün Vali 500 çadırla, ekmek ve peynir yüklü kamyonları deprem bölgesine göndermişti. İki Bakan Erzurum'a gelmiş harap olan köyleri gözleriyle görmüş ve felâkete uğrayan yerler hakkında icap eden tedbirleri almıştı. Depremin dördüncü günü bilhassa ordunun yardımıyla, her türlü onarma ve ihtiyaç için gerekli malzeme bölgeye akmaya başlamıştı. (TBMM Tutanak Dergisi, C: 21, Dönem 8, Toplantı 4, 1950: 53-56)

Vehbi Kocagüney'in bölge milletvekili olarak verdiği bu bilgiler çok değerlidir. Açıklamalara bakılacak olursa Hükûmet, depremzedelerin acil ihtiyaçlarını karşılama hususunda çok iyi bir sınav vermişti.

Bu depreme dair bir diğer yardım kararı da 22 Aralık 1949 tarihinde Bakanlar Kurulunda çıkacaktı. Karara göre depremden zarar gören Bingöl, Kiğ 1 ve Karlıva'daki genel bütçeden aylık veya ücret alan memurlarla, hizmetli, emekli, dul ve yetimlere ikişer maaş nispetinde avans verilmesi 4623 sayılı Kanun'un 28. maddesine göre kararlaştırılmıştı. (BCA, Fon No: 301812 Yer No: 121 $9113)$

Daha önceki örneklerde olduğu gibi Bingöl depreminde de zarar gören vergi mükelleflerinin bazı vergileri silinmişti. Kığı ve Karlıvva ilçesinde depremden zarar gören mükelleflerin tahsil edilmemiş verginin tutarı 24.797 lira 40 kuruş Özel İdare vergilerinin silinmesine 4623 sayılı Kanun'un 27. maddesine göre Bakanlar Kurulunca 13 Nisan 1950'de karar verilmişti. (BCA, Fon No: 301812 Yer No: 122 20 35)

Yine Bingöl'ün Kiğ ilçesinde 17 Ağustos 1949'da meydana gelen deprem sebebiyle burada oturanların ruhsat tezkeresi harcından, kazanç vergisinden, iktisadi buhran vergisinden, fevkalade zamdan, davar, deve vergisinden, diğer hayvanlar vergisinden, mahkeme harcından, muamele vergisinden, veraset ve intikal vergisinden, zam cezasından, damga resminden ki toplam 57.284.13 lira vergi borçlarının ertelenmesi Bakanlar Kurulunca 9 Ağustos 1950'de kabul edilmişti. (BCA, Fon No: 3018127123667 )

\section{B. Kuraklık/Kıtlık, Aşırı Yağış, Sel ve Taşkınlar Sebebiyle Yaşanan Doğal Afetler ve Yapılan Yardımlar}

Doğu ve Güneydoğu Anadolu bölgelerinde her coğrafyada olduğu gibi deprem harici doğal afetler de yaşanmıştı. Bu başlık altında kuraklık/kıtlık, aşırı yağışların sebep olduğu seller ve taşkınlardan kaynaklanan doğal afetler incelenmiştir. Bahsedeceğimiz afetler incelediğimiz 19231950 yılları arasında bölgede yaşanan tüm afetler değildir şüphesiz. Biz burada bölgede incelediğimiz yıllar içinde yaşanan kuraklık, sel ve taşkın afetlerinden yalnızca can ve kayda değer anlamda mal kaybına sebep olan afetleri ele aldık.

Ele alacağımız ilk afet, aşırı yağışlardan ya da iklim şartlarının mevsim normal değerlerinden farklı gitmesinden kaynaklanan kıtlık afettir. Örneğin 1932-1933 senesi kış mevsimi bölgede pek şiddetli geçmişti. Bu durum bölge halkının dışarıdan erzak teminini güçleştirmişti. Bu sebepten dolayı ahali ertesi yıl ekeceği tohumluklarını dahi yemek zorunda kalmıştı. Ancak bu da ihtiyaca kâfi gelmeyince 10 Mayıs 1933 tarihinde Bayazıt Valiliği, durumdan Dâhiliye Vekâletini acil olarak haberdar etmişti. Vilayetten gelen yazıya göre bir haftadan beri Tuzluca kazası ahalisi, memur ve jandarmaları un ve buğday yokluğundan dolayı pek çok sıkıntılar çekmekteydi. Hatta ahalinin bir kısmı ot ile karnını doyurmaktaydı. Bayazıt Valiliği durumu bu şekilde Dâhiliye Vekâletine arz 
ettikten sonra Tuzluca ahalisine un ve buğdayın yetiştirilmesi için Hilali Ahmer ve Ziraat Bankası gibi kurumlara "süratle" yardım yapmaları için Vekâletten talimat verilmesini istemişti. (BCA, Fon No: 301000 Yer No: 1842692 lef 6) Bayazit vilayetinden gelen bu istek 13 May1s 1933'te Başvekâlete iletilmişti. (BCA, Fon No: 301000 Yer No: 1842692 lef 5) Başvekâlet makamı hemen 14 Mayıs 1933 günü Ziraat ve Sihhat ve İçtimai Muavenet Vekâletlerine verdiği talimatla gereken yardımların yapılması talimatını vermiști. Sıhhat ve İçtimai Muavenet Vekâletine verilen talimatla Hilâl-i Ahmer Cemiyetinin bölge halkına acilen yardım ulaştırması istenmiști. (BCA, Fon No: 3010 00 Yer No: 1842692 lef 9) Ziraat Vekâletine verilen talimatta bölge halkına acil olarak buğday gönderilmesi istenirken aynı zamanda halk elindeki ekeceği tohumluğu yemek zorunda kaldığ için gelecek sene de aynı sıkıntıların yaşanmaması için tohumluk buğday da gönderilmesi istenmişti. (BCA, Fon No: 301000 Yer No: 1842692 lef 10-11) Başvekâlet bu șekilde alakadar Bakanlıklara gerekli talimatları verirken Dâhiliye Vekâletine de aynı tarihte yazdığı bir diğer yazıda Tuzluca halkının bir an önce sefaletten kurtarılması için Dâhiliye Vekâletince civar vilayetlerin harekete geçirilmesini istemişti. (BCA, Fon No: 301000 Yer No: 1842692 lef 1)

Sıhhat Vekâleti kendisine verilen talimatı hemen yerine getirmişti. Başvekâletten talimatın geldiği 14 Mayıs günü Hilâl-i Ahmer Cemiyeti, Bayazıt vilayetine 1.000 lira yardım göndermişti. (BCA, Fon No: 301000 Yer No: 1842692 lef 4)

Aslında bu açlığın sadece Tuzluca kazasında olmadığı civardaki Bayazıt, Iğdır ve Diyadin kazalarında da yaşandığını 19 Haziran tarihli bir belgeden anlıyoruz. $\mathrm{Bu}$ tarihte Dâhiliye Vekâletinden Başvekâlete yazılan yazıya göre Hilâl-i Ahmer Cemiyetinin başta vermiş olduğu 1.000 liralık yardıma ilave olarak daha sonra 1.500 lira daha yardım yapılmış ve zikredilen yerler halkının ihtiyaçları karşılanmıştı. Bu gönderilen yardımlar sayesinde 15 Haziran'da Birinci Umumi Müfettişlikten gönderilen yazıdan anlaşıldığına göre Vilayette açlık namına bir şey kalmamıştı. (BCA, Fon No: 301000 Yer No: 1842692 lef 3)

Bölgede yaşanan yiyecek sıkıntısından aslında sadece insanlar değil hayvanlar da olumsuz etkilenmişti. 12 Mayıs 1933 'te Van vilayetinden Dâhiliye Vekâletine gönderilen bir yazıya göre "darlık dolayısıyla" Van ve kazalarında 63.010 koyun, 12.390 keçi, 3431 sığır, 354 manda, 573 at, 305 eşek, 34 katır ve iki deve ki toplamda 80.149 hayvan ölmüştü. Yeni doğan kuzu ve oğlak kaybı ise \% 75 idi. (BCA, Fon No: 301000 Yer No: 1842692 lef 2)

Bölgede 1933 yılında yaşanan sıkıntıdan Kars vilayetinin Posof, Ardahan ve Göle kazaları da etkilenmişti. Bu sıkıntılar ertesi yıl da aynen devam etmişti. Dönem Kars Valisi Cevdet Bey (Ertuğrul), Dâhiliye Vekâletine 21 Şubat 1934 tarihinde yazdığ 1 yazıda zikredilen kazaların yiyeceklerinin kalmadığını, kazalardan gelen bilgilere göre yörede açlık ve ölüm tehlikesinin baş gösterdiğini belirtmişti. Vali Cevdet Bey, Hilâl-i Ahmer Cemiyetinden daha önce gelen 500 lira yardımın muhtaçları ancak on gün kadar idare edeceğinden, tekrardan Ziraat Vekâleti ve Ziraat Bankasınca yemeklik ve tohumluk buğday için acele yardım yapılmasını istemişti. (BCA, Fon No: 301000 Yer No: 815311 lef 6) Dâhiliye Vekâleti aynı gün, 21 Şubat'ta durumdan Başvekâleti haberdar etmişti. (BCA, Fon No: 301000 Yer No: 815311 lef 5) Başvekâlet ise ilgili Ziraat ve Sihhat ve İçtimai Muavenet Vekâletini hemen harekete geçirmişti. (BCA, Fon No: 301000 Yer No: 815311 lef 4) Bu Vekâletlerden Sihhat ve İçtimai Mavenet Vekâleti yazdığı cevabi yazıyla kışın şiddetli ve uzun geçmesinden dolayı açlığa maruz kalan bu yerler halkı için Hilâl-i Ahmer Cemiyetince 16 Nisan 1933 'te 1.500 ve 18 Şubat 1934 'te 500 lira gönderildiğini ayrıca bölgeye mahallinde incelemeler yapmak üzere Hilâl-i Ahmer müfettişinin gönderilip yardımların gelen raporlar doğrultusunda devam edeceğini bildirmişti. (BCA, Fon No: 301000 Yer No: 815311 lef 2)

Yardımlar bölge halkına daha sonra da devam etmişti. 1934 yılı mevsim şartları iyi gitmediği için Hükûmet tarafindan Bayezid, Kars, Van, Muş ve Erzurum'un mağdur duruma düşmüş olan 
halkına tohumluk yardımına dair 2 Nisan 1934 tarihinde bir Kararname çıkartılmıştı. (BCA, Fon No: 301812 Yer No: 4318 1)

Doğu vilayetlerinde baş gösteren kuraklık ve kıtlık afetlerinden dolayı mağdur duruma düşmüş afetzedeler için Hükûmetin yardım araçlarından biri de çiftçilerin borçlarının ertelenmesi uygulamasıydı. Örneğin 1936 yılında Diyarbakır ve Erzincan'da yaşanan kuraklıktan dolayı mahsullerinin zarar görmesinden dolayı mağdur duruma düşmüş olan 1.738 çiftçinin Ziraat Bankasına olan borç taksitlerinin ertelenmesi 25 Ocak 1937'de çıkarılan Kararname'yle mümkün olmuştu. (BCA, Fon No: 301812 Yer No: 715 14)

Bu yıllarda yaşanan kuraklığın şiddeti bazen o kadar fazla oluyordu ki devletin ülke sathında uygulamaya çalıştı̆̆ 1 politikaları bile etkileyebiliyordu. Bilindiği üzere 1934 yılında 2510 sayılı İskân Kanunu çıkarılmıştı. Bu Kanun ile Türkiye'de yaşayan nüfusun dağılışı düzenlenmek istenmişti. (T.C. Resmî Gazete, 21 Haziran 1934, Sayı: 2733; TBMM Zabıt Ceridesi, Devre: IV, C: 23, İçtima: 3, 1934: 67-77, 140-160)

Kanun çıkarıldıktan sonra 1934-1938 yılları arasında Bulgaristan, Romanya, Yugoslavya ve diğer ülkelerden 46.544 hanede 174.280 göçmen nüfus gelmişti. Bu nüfustan 21.290 kişi Doğu vilayetlerine yerleştirilmişti. (BCA, Fon No: 490100 Yer No: 2138441 lef 64)

Gelen göçmenlerin yerleştirildiği Doğu vilayetlerinden biri de Diyarbakır vilayeti idi. Diyarbakır'ın Merkez, Bismil, Çınar ve Ergani ilçelerine 1937-1939 y1llarında Bulgaristan ve Romanya'dan gelen 1.363 hanede 5.452 nüfus göçmen iskân edilmişti. Gelen göçmenlere hayatlarını idame ettirmek için Hükûmet tarafından ev, toprak ve zirai alet, edevat verilmişti. Ancak 1941 ve 1942 yıllarında yaşanan kuraklık ve süne haşeresi sebebiyle zor durumda kalan göçmenlerin bir kısmı iskân mahallerini terk ederek Eskişehir, Konya, Kocaeli gibi yerlere gitmişlerdi. Devlet daha sonra giden bu göçmenleri tekrar eski yerlerine döndürmeye çalışsa da 1948 yılına gelindiğinde giden 187 hane nüfus geri gelmemişti. (TBMM Tutanak Dergisi, Dönem: 8, C: 14, Toplant1 3, 1949: 348-353)

Yine Diyarbakır'da 1942 yılında yaşanan kuraklıktan etkilenen 440 çiftçinin borç taksitlerinin ertelenmesi 25 Mayıs 1943'te kararlaştırılırken (BCA, Fon No: 3018127 Yer No: 102 37 13) daha sonraki yıllarda tekrardan bazı Doğu vilayetlerinde yaşanan kuraklıktan dolayı Malatya, Erzurum, Erzincan, Gaziantep, Malatya ve Adıyaman çiftçilerinin 1947-1948 y1lı borç taksitlerinin ertelenmesine 22 Kasım 1948'de karar verilmişti. (BCA, Fon No: 301812 Yer No: 11771 20)

Doğu vilayetlerinde 1923-1950 yılları arasında meydana gelen aşırı ani yağışların sebep olduğu sel felâketleri, bölge insanı üzerinde maddî manevi birçok tahribata yol açmıştı.

Bu dönemde yaşanan bazı sel felaketlerine örnek olarak şunlar verilebilir: 2 Ağustos 1932'de Erzurum'da şiddetli yağmur sebebiyle Türbe deresinin taşması üzerine bazı köprülerin yıkıldığı, evlerin hasara uğradığı felakette 3 çocuk ölmüştü. (BCA, Fon No: 301000 Yer No: 1178206 lef 1-2) 8 Ağustos 1932'de Kars Sarıkamış'ın İssisu köyünü sel basmış, 12 ev kısmen harap olmuş, 50 koyun ve 12 aygır telef olmuştu. (BCA, Fon No: 3010007 Yer No: 117820 7) Elâziz Baskil kazasının Muşar nahiyesine bağlı Kele köyünde 28 Mayıs 1934 gecesi sel felaketi yaşanmıştı. Bu felakette iki kız çocuğu boğulmuş, 38 ev harap olmuştu. (BCA, Fon No: 301000 Yer No: 117821 5) 23 Mayıs 1936'da Kars'ın Hacihalil köyüne yağan yağmur 10 haneyi yıkmış ve bu köyden bir kadın ölmüştü. (BCA, Fon No: 301000 Yer No: 118823 4) 9 Temmuz 1938 tarihinde Erzincan vilayeti Cimin nahiyesinin Keleriç, Piskidağ, Kalolar köyleri ve mezralarında 19 kişis selden ölmüştü. Bu köylerden 93 ev sele kapılmış mektepler tamamen yıkılmıştı. (BCA, Fon No: 301000 Yer No: 11882431 lef 3-4) Urfa vilayetinin 3 Aralık 1938 tarihli raporuna göre Harran'da Tektek dağlarındaki göçebeler sel sularına kapılmıştı. Yine Siverek'in Karukmizar ve Salur köylerinde 27/28 Kasım 1938 tarihinde yaşanan sel felaketinde 42 kişi boğulmuştu. (BCA, Fon No: 3010007 Yer No: 118826 9) 1942 yılı sonbaharında Muş'ta 80 günden beri devamlı yağmakta olan yağmurların 
etkisi ile 12 ev yıkılmış, 13 kişi ölmüş ve 3 kişi de yaralanmıştı. (BCA, Fon No: 3010007 Yer No: 1208499 lef 24)

Bölgede yaşanan bu sel felaketleri gibi bir de taşkınlardan kaynaklanan felaketler vardı. Özellikle bölge coğrafya olarak yüksek bir bölge olduğu için buradaki Fırat Nehri aşırı yağışların olduğu dönemlerde taşıp çok büyük felaketlere yol açabiliyordu.

İşte bu taşkınların civar mahallere verdiği zararların önüne geçmek maksadıyla devlet 1937 yılında bir çalışma yapmıştı. Nafia Vekâletine bağlı Sular Umum Müdürlüğü Müşaviri Doktor Görner'in hazırlayıp 18 Temmuz 1937 tarihinde Dâhiliye Vekâletine sunulan rapor Şükrü Kaya tarafindan 7 Mayıs 1938'de Başvekâlete gönderilmişti. Raporda, her sene meydana gelen bu taşkınların önlenebilmesi için Fırat'ın ıslah edilmesi isteniyordu. Bu 1slah işi, Furat'ın belirlenmiş bir sabit bir yatağa alınması ve kenarlarına yüksek setler yapılması şeklinde olacaktı. (BCA, Fon No: 30 1000 Yer No: 1569616 lef 3-4)

Nehir boyunda yer alan mesken ve arazi sahipleri devletten bu işin bir an önce çözülmesini istiyordu. Fırat taşkınları konusunda, Erzincan'ın Çolhasa köyü muhtar ve azaları 15 Aralık 1938 tarihinde doğrudan Başvekâlete yazdıkları yazıda taşkınlara karşı devletin setler yaparak yardım etmesini istemişlerdi. (BCA, Fon No: 301000 Yer No: 11882613 lef 2) Başvekâlet, vaziyet hakkında Nafia Vekâletinden bilgi istemişti. Alınan 21 Mart 1939 tarihli bilgi doğrultusunda Erzincan vilayetine 23 Mart 1939'da yazılan yazıdan anlaşıldığına göre 1939 senesi içinde Şıhlı, Vaskirt, Hamizisi ve Molla köyler civarında çeşitli uzunlukta kanallar inşa edilmekte olduğu, bunların vereceği neticelere göre taşkına maruz kalan diğer kısımların da tetkik edileceği bildirilmişti. (BCA, Fon No: 301000 Yer No: 11882613 lef 1)

$\mathrm{Bu}$ yazışma sonrasında bu yıllarda Fırat Nehri'nin 1slahına dair başka herhangi bir gelişme yaşanıp yaşanmadığını belgelerden takip edememekteyiz. Ancak muhtemelen bu yıllarda taşkınlara karşı istenilse de daha fazla bir şey yapılamamıştır. Çünkü bu yılın sonlarına doğru patlak veren Dünya Harbi bu tarz yatırımları sonraki tarihlere bıraktıracak cinstendi.

\section{Sonuc}

Günümüzde olduğu gibi geçmişte de birçok doğal afet yaşanmıştır. İnsanoğlu bu afetlerin yaşanmasına karşı hiçbir şey yapamasa da en azından afetlerin yıkıcı etkisini minimize etmek için bilimsel çalışmalara devam etmektedir. Yapılan bu çalışmaların daha geçerli, doğru bilgiler verebilmesi için şüphesiz tarihte yaşanmış olan doğal afetlerin bilgisine de ihtiyaç vardır. Bu bağlamda yapılan tarih çalışmaları değer kazanmaktadır. Çünkü tarih çalışmaları sayesinde geçmişte yaşanan doğal afetlere ilişkin günümüzde ilim adamalarının ellerinde olmayan istatistiki bilgiler ortaya çıkarılabilmektedir. Doğal afetlere ilişkin yapılan tarih çalışmalarının faydalarından biri de yaşanan afetlerde teknik bilgilerin yanı sıra aynı zamanda dönem hakkında sosyal, ekonomik, kültürel hatta siyasi bilgiler elde edilmesidir.

Biz bu çalışmada 1923-1950 yılları arasında ülkenin Doğu vilayetlerinde yaşanan deprem, kuraklık/kıtlık, aşırı yağışların sebep olduğu sel ve taşkın gibi doğal afetler konusunu işledik. Yaşanan bu afetlere karşı Cumhuriyet Türkiye'si daha ilk yılında önündeki onca meseleye rağmen afetlerin verdiği tahribatı ortadan kaldırmak ve afetzedelerin yaralarını sarmak için seferber olmuştu. 1924 y1lında yaşanan Erzurum depreminde devletin Reis-i Cumhur'u Gazi Mustafa Kemal bizzat deprem bölgesine giderek felaketzedelerin hem madden hem de manen devlet olarak yanlarında olunduğu mesajını vermişti. Gazi, bu ziyaretinde aynı zamanda felaketzedelerin yaralarını sarmak için tüm yurt sathında bir yardım seferberliği başlatmıştı. Böylelikle devlet-millet seferberliği sayesinde depremin yaraları tez zamanda sarıldı. Türk milletinin uzak yakın hiç fark etmeksizin hepsinin bir afet karşısında topyekûn afetzedelerin yanında yer almasına bir diğer güzel örnek de 1939 yılında yaşanan Erzincan depremi idi. Bu depremde devrin Cumhurbaşkanı İsmet İnönü deprem 
bölgesine gitmiş, depremzedelerin acılarına ortak olmuştu. Devlet başkanının yanı sıra depremin yaşandığı gün Meclis çatısı altında Milli Yardım Komitesinin kurulması da bu depreme devletin tüm kurumlarıyla sahip çıktığının en güzel örneği idi. Bu arada yaşanan bu insanlık felaketine dışarıdan gelen yardımları da unutmamak gerekmektedir. Milletin yekvücut olup devletiyle birlikte afetzedelerin yardımına koşması dönem boyunca yaşanan tüm afetlerde karşımıza çıkan bir durum olmuştur. Bu durum da aynı coğrafyada yaşayan insanların sevinçte bir arada olduğu gibi zor zamanlarda da birlikte olup acıları dindirerek millet olmanın gerekliliğini yerine getirmenin en güzel örneği olarak karşımıza çıkmıştır.

\section{Kaynakça}

\section{Arşiv Belgeleri}

Cumhurbaşkanlığı Devlet Arşivleri Başkanlığı Cumhuriyet Arşivi (BCA)

BCA, Fon No: 10900 Yer No: 47013601.

BCA, Fon No: 30100 Yer No: 1211769 lef 2.

BCA, Fon No: 30100 Yer No: 1212768.

BCA, Fon No: 30100 Yer No: 1216770.

BCA, Fon No: 30100 Yer No: 4023712.

BCA, Fon No: 30100 Yer No: 775482.

BCA, Fon No: 301000 Yer No: 1178206 lef 1-2.

BCA, Fon No: 301000 Yer No: 1178215.

BCA, Fon No: 301000 Yer No: 1188234.

BCA, Fon No: 301000 Yer No: 11882431 lef 3-4.

BCA, Fon No: 301000 Yer No: 11882613.

BCA, Fon No: 301000 Yer No: 11882733.

BCA, Fon No: 301000 Yer No: 11910844.

BCA, Fon No: 301000 Yer No: 11984411.

BCA, Fon No: 301000 Yer No: 1198446.

BCA, Fon No: 301000 Yer No: 11983910 lef 2.

BCA, Fon No: 301000 Yer No: 1198405.

BCA, Fon No: 301000 Yer No: 11984514.

BCA, Fon No: 301000 Yer No: 11984819.

BCA, Fon No: 301000 Yer No: 12085012.

BCA, Fon No: 301000 Yer No: 12085014.

BCA, Fon No: 301000 Yer No: 12085015.

BCA, Fon No: 301000 Yer No: 12085016.

BCA, Fon No: 301000 Yer No: 12085018.

BCA, Fon No: 301000 Yer No: 12085021. 
BCA, Fon No: 301000 Yer No: 1569616 lef 3-4.

BCA, Fon No: 301000 Yer No: 1792354.

BCA, Fon No: 301000 Yer No: 1842692.

BCA, Fon No: 301000 Yer No: 815311 lef 6.

BCA, Fon No: 30100 0/11983911.

BCA, Fon No: 30100071178207.

BCA, Fon No: 30100071188269 .

BCA, Fon No: 30100071198381.

BCA, Fon No: 30100071198433.

BCA, Fon No: 301000711984818.

BCA, Fon No: 30100071208491.

BCA, Fon No: 30100071208499 lef 24 .

BCA, Fon No: 3010007 Yer No: 1178183.

BCA, Fon No: 3010007 Yer No: 1198377.

BCA, Fon No: 301811 Yer No: 10297.

BCA, Fon No: 301811 Yer No: 1143.

BCA, Fon No: 301811 Yer No: 114315.

BCA, Fon No: 301811 Yer No: 11462 lef 1.

BCA, Fon No: 301811 Yer No: 11468 lef 2.

BCA, Fon No: 301811 Yer No: 12689.

BCA, Fon No: 301811 Yer No: 12692.

BCA, Fon No: 301811 Yer No: 37109.

BCA, Fon No: 301811 Yer No: 9259.

BCA, Fon No: 301812 Yer No: 116222.

BCA, Fon No: 301812 Yer No: 117646.

BCA, Fon No: 301812 Yer No: 1177120.

BCA, Fon No: 301812 Yer No: 1206413.

BCA, Fon No: 301812 Yer No: 120824.

BCA, Fon No: 301812 Yer No: 1219113.

BCA, Fon No: 301812 Yer No: 1222035.

BCA, Fon No: 301812 Yer No: 43181.

BCA, Fon No: 301812 Yer No: 565218.

BCA, Fon No: 301812 Yer No: 71514.

BCA, Fon No: 301812 Yer No: 90204. 
BCA, Fon No: 3018127 Yer No: 1023713.

BCA, Fon No: 30181 Yer No: 27123667.

BCA, Fon No: 3018127 Yer No: 916016.

BCA, Fon No: 490100 Yer No: 135301.

BCA, Fon No: 490100 Yer No: 15824451.

BCA, Fon No: 490100 Yer No: 15824452.

BCA, Fon No: 490100 Yer No: 15824492.

BCA, Fon No: 490100 Yer No: 15824492 lef 7-11.

BCA, Fon No: 490100 Yer No: 15834562.

BCA, Fon No: 490100 Yer No: 15834552.

BCA, Fon No: 490100 Yer No: 15843462.

BCA, Fon No: 490100 Yer No: 15864711 lef 3-5.

BCA, Fon No: 490100 Yer No: 2138441 lef 64.

BCA, Fon No: 490100 Yer No: 6471491 lef 72.

BCA, Fon No: 4901007 Yer No: 15844591.

BCA, Fon No: 490100 Yer No: 15854701.

\section{Resmî Yayınlar}

Ayın Tarihi, Kasım 1939.

Ayın Tarihi, Aralık 1939.

Ayın Tarihi, 31 Mart 1948.

Ayın Tarihi, 3 Eylül 1949.

Ayın Tarihi, Şubat 1943.

Resmî Cerîde, 24 Kasım 1924, Sayı: 79.

T.C. Resmî Gazete, 21 Haziran 1934, Say1: 2733.

T.C. Resmî Gazete, 2 Ocak 1940, Say1: 4399.

T.C. Resmî Gazete, 25 Ocak 1940, Sayı: 4416.

T.C. Resmi Gazete, 30 Kasim 1940, Say1: 4674.

T.C. Resmî Gazete, 30 Kasım 1940, Sayı: 4674.

T.C. Resmi Gazete, 4 Mart 1940, Say1: 4449.

T.C. Resmi Gazete, 13 Mart 1940, Sayı: 4457.

T.C. Resmî Gazete, 10 Ağustos 1940, Say1: 4584.

T.C. Resmî Gazete, 26 Eylül 1941.

T.C. Resmî Gazete, 22 Temmuz 1944, Say1: 5763. 
T.C. Resmî Gazete, 12 Temmuz 1948, Say1: 6955.

T.C. Resmî Gazete, 10 Mart 1950, Say1: 7453.

T.C. Resmî Gazete, 18 Mart 1950, Say1: 7460.

TBMM Albümü 1920-2010, C: 1, TBMM Yayınları, Ankara 2010.

TBMM Tutanak Dergisi, C: 12, Dönem VIII, Toplantı 2, TBMM Matbaas1, 1948.

TBMM Tutanak Dergisi, C: 14, Dönem: 8, Toplantı 3, TBMM Matbaası, 1949.

TBMM Tutanak Dergisi, C: 16, Dönem 8, Toplantı 3, TBMM Basımevi, 1949.

TBMM Tutanak Dergisi, C: 17, Dönem 7, Toplantı 2, TBMM Basımevi, 1945.

TBMM Tutanak Dergisi, C: 20, Dönem 7, Toplantı 3, TBMM Basımevi, 1946.

TBMM Tutanak Dergisi, C: 21, Dönem 8, Toplantı 4, TBMM Matbaası, 1950.

TBMM Tutanak Dergisi, C: 24, Dönem 7, Toplantı 3, TBMM Matbaası, 1946.

TBMM Tutanak Dergisi, C: 24, Dönem 8, Toplantı 4, TBMM Basımevi, 1950.

TBMM Tutanak Dergisi, C: 25, Dönem 8, TBMM Matbaası, 1950.

TBMM Zabıt Ceridesi, C. 20, Devre VI, İçtima 2, TBMM Matbaası, 1941.

TBMM Zabıt Ceridesi, C. 3, Devre 5, İçtima F., TBMM Matbaası, 1935.

TBMM Zabıt Ceridesi, C. 7, Devre IV, İçtima 1, TBMM Matbaası, 1940.

TBMM Zabıt Ceridesi, C: 12, Devre VII, İçtima 1, TBMM Matbaası, 1944.

TBMM Zabıt Ceridesi, C: 13, Devre VI, İçtima 1, TBMM Matbaası, 1940.

TBMM Zabıt Ceridesi, C: 14, Devre 6, İçtima 2, TBMM Matbaası, 1940.

TBMM Zabıt Ceridesi, C: 20, Devre VI, İçtima 2, TBMM Matbaası, 1941.

TBMM Zabıt Ceridesi, C: 8, Devre VI, İçtima 1, TBMM Matbaası, 1940.

TBMM Zabıt Ceridesi, Devre: IV, C: 23, İçtima: 3, TBMM Matbaası, 1934.

\section{Süreli Yayınlar}

Akşam, 4 Mayıs 1935.

Akşam, 4 Ocak 1940.

Akşam, 17 Şubat 1940

Cumhuriyet, 29 Aralık 1939.

Cumhuriyet, 30 Aralık 1939.

Cumhuriyet, 31 Aralık 1939.

Cumhuriyet, 4 Ocak 1940.

Cumhuriyet, 12 Şubat 1940.

Cumhuriyet, 17 Şubat 1940.

Hâkimiyeti Milliye, 16-30 Eylül 1924.

Hâkimiyeti Milliye, 7 Haziran 1930. 
İzmir Yeni Asır, 29 Aralık 1939.

Son Posta, 31 Aralik 1939.

Son Telgraf, 31 Aralık 1939.

Ulus, 28 Aralık 1939.

Ulus, 3 Ocak 1940.

Ulus, 7 Haziran 1946.

Yeni Sabah, 29 Aralık 1939.

\section{Kitaplar}

Akgün, S.Ç. ve Uluğtekin, Murat. (2001). Hilâl-I Ahmer'den Kızılay'a II. Kızılay Yayınları.

Atatürk'ün Söylev Ve Demeçleri, C: 2. (1997). Atatürk Kültür, Dil Ve Tarih Yüksek Kurumu Atatürk Araştırma Merkezi. https://doi.org/10.1501/ilhfak_0000000966

Atnur, İ. E. (2006). Reisicumhur'un Doğu Incelemeleri (1924 Erzurum Depremi). Ebabil Yayınları.

Çapa, M. "Erzurum Depremi Ve Cumhurbaşkanı Gazi Mustafa Kemal'in Erzurum Ziyareti". 23 Temmuz Erzurum Kongresi Ve Kurtuluştan Günümüze Erzurum 1. Uluslar Arası Seтроzуuтu (23-25 Temmuz 2002- Erzurum). Yay. Haz.: Yavuz Aslan, Salim Gökçen, Atam Yay. https://doi.org/10.17498/kdeniz.337074

Celal Bayar Diyor Ki 1920:1950 Nutuk-Hitabe-Beyanat-Hasbihal, (1951). Haz.: Nazmi Sevgen.

Darkot, B. (1955). "Türkiye'nin Coğrafi Bölgeleri Hakkında". Türk Coğrafya Dergisi. Sayı: 13-14. 1955.

Küçükuğurlu, Murat. (2012). Türk Siyasî Tarihinde Erzurum (1923-1950). Atam Yay.

Pampal, S. (2000). Depremler. Alfa Yayınları.

Şahin, C., Sipahioğlu, Ş. (2003). Doğal Afetler ve Türkiye.

Tanpınar, A. H. (1960). Beş Şehir. TTK Yayınları.

Türkiye'de Deprem Gerçeği ve TMMOB Makina Mühendisleri Odası'nın Önerileri Oda Raporu. (2012)

Yavuz, E. (2017). 1939 Depremi (Erzincan Ve Bölgeye Etkisi). Arı Sanat Yayınevi.

\section{Makaleler}

Atay, F.R. "Milli Yardım Seferberliği". Ulus, 28 Aralık 1939.

Aykaç, F.A. "Vazife Başına". Cumhuriyet, 30 Aralık 1939.

Benice, E.i. "Hariçten Gelen Yardım". Son Telgraf, 31 Aralık 1939.

Birgen, M. "Kara Felaket". Son Posta, 31 Aralık 1939.

Kalemli, H. (2010). "1924 Erzurum Depreminde Yurtdışından Yapılan Yardımlar". Atatürk Üniversitesi Sosyal Bilimler Enstitüsü Dergisi $14 \quad$ (2), 1-19. https://doi.org/10.9775/kausbed.2016.013

Nadi, N. "Büyük Milli Felaketimiz Karşısında". Cumhuriyet, 29 Aralık 1939.

Nadi, Y. "Milletimizin Hassasiyeti". Cumhuriyet, 31 Aralık 1939.

Ocakoğlu, H. "Felaket Karşısında". İzmir Yeni Asır, 29 Aralık 1939. 
Tekir, S. (2012). "Kars Ve Çevresinde Depremler (1924-1941)". History Studies, Prof. Dr. Enver Konukçu Armağan1, 423-436. https://doi.org/10.9737/hist_480

Yalçın, H. C. "Milli Bir Felaket". Yeni Sabah, 29 Aralık 1939.

Yüksel, A. (2002). "1939 Erzincan Depremi Hakkında Bazı Düşünceler". Tarih Boyunca Anadolu'da Doğal Afetler Ve Deprem Semineri 22-23 Mayıs 2000, Bildiriler 2. Bask1.

\section{Tezler ve İnternet Adresleri}

Köse, R. (2019). CHP ve DP Hükûmetleri Dönemlerinde Doğu ve Güneydoğu Anadolu Politikalart. Yayımlanmamış Doktora Tezi, İstanbul Üniversitesi Sosyal Bilimler Enstitüsü. https://doi.org/10.17336/igusbd.446879

http://www.koeri.boun.edu.tr/sismo/2/deprem-bilgileri/buyuk-depremler/ (Çevrimiçi: 27.05.2020) www.varto.gov.tr/ilcemiz-genel-bilgiler (Çevrimiçi: 20 Nisan 2020) 